\title{
THE MAMMALS OF THE ANDAMAN AND NICOBAR ISLANDS.
}

\author{
By Gerrit S. Milleer, Jr. \\ Assistant Curator, Division of Mammals.
}

\section{INTRODUCTION.}

The months of January, February, and March, 1901, were spent by Dr. W. L. Abbott and Mr. C. B. Kloss in exploring the Andaman and Nicobar Islands. Valuable collections were made in several branches of zoology and in anthropology, all of which have been presented to the United States National Museum. This paper contains an account of the mammals, of which 170 specimens were secured, chiefly by Dr. A.hbott, Mr. Kloss having turned his attention more particularly to the birds.

Leaving Victoria Point on December 26, 1900, Dr. Abbott and Mr. Kloss proceeded first to the Andamans, where they touched successively at Barren Island, Henry Lawrence Island, South Andaman Island, North Cinque Island, and Little Andaman Island. Thence they sailed to the Nicobars, visiting Car Nicobar, Tillanchong Island, Trinkut Island, Kamorta Island, Kachal Island, Nankauri Island, Little Nicobar Island, and Great Nicobar Island.

Except on North Cinque Island, mammals were obtained at every locality visited. These represent such a large part of the fauna hitherto known, and, moreover, so many species not before detected, that I have extended the scope of this paper to include all of the mammals recorded from the Andaman and Nicobar islands. A discussion of their mutual relationships and probable origin is given in the summary following the systematic list of species.

Only one general account of the mammals of the Andaman and Nicobar Islands has hitherto been published. This was by Blyth, and it formed part of the appendix to Mouat's Adventures and Researches among the Andaman Islanders (1863). The remainder of the literature of the subject is so scattered that it is almost impossible to bring it completely together. The bibliography at the end of the present 
article, however, probably contains the titles of all the more important papers on the subject.

The Andaman and Nicobar islands, an outline map of which is given in the accompanying figure, lie in the eastern side of the Bay of Bengal. They form an almost continuous chain from off the southern coast of Pegu nearly to the northern extremity of Sumatra and parallel with the northern portion of the Malay Peninsula. For the most part they are densely forested, and the climate, though tropical, is not of the hottest. From the nearest land, as well as from each other, both Andamans and Nicobars are separated by water of very considerable depth. In this respect they differ widely from the other islands in the neighborhood of the Malay Peninsula.

\section{SYSTEMATIC LIST OF SPECIES. \\ Genus DUGONG Lacépède.}

DUGONG DUGON (Müller).

1859. Halicore indicus Blyth, Journ. Asiat. Soc. Bengal, XXVIII, p. 271. (Andamans.)

Bones of the dugong have been found in the huts of the native Andamanese.

\section{Genus SUS Linnæus.}

\section{SUS ANDAMANENSIS Blyth.}

1858. Sus andamanensis Blyth, Journ. Asiat. Soc. Bengal, XXVII, p. 267. (Port Blair, South Andaman Island.)

The pig appears to have been the first of the Andaman mammals to attract the attention of explorers. In $1827 \mathrm{~J}$. E. Alexander published a notice regarding the little Andaman Island, Bay of Bengal, ${ }^{1}$ in which he says:

Ranged in a row around the walls (of a native hut) were the smoked skulls of a diminutive hog, the canine teeth shorter than in other species of sus in eastern countries, the jaws fastened together by strips of rattan (Pl. I, fig. 1).

The figure is quite unrecognizable beyond the fact that it was evidently intended to represent the skull of a pig, but the description leaves no doubt as to the identity of the animal. Thirty-one years later the animal was described by Blyth as Sus andamanensis ${ }^{2}$ from skulls collected at Port Blair, South Andaman Island. In a subsequent account of collections from Port Blair, ${ }^{3}$ Blyth adds a few words concerning its external appearance, erroneously stating that the tail is reduced to a mere tubercle. A year later, ${ }^{4}$ however, he recognizes

\footnotetext{
${ }^{1}$ Edinburgh New Philos. Journ., II (October-December, 1826), 1827, pp. 43-48, pl. I.

${ }^{2}$ Journ. Asiat. Soc. Bengal, XXVII, 1858, p. 267.

${ }^{3}$ Idem, XX VIII, 1859, p. 271.

${ }^{4}$ Idem, XXIX, 1860, p. 104.
} 


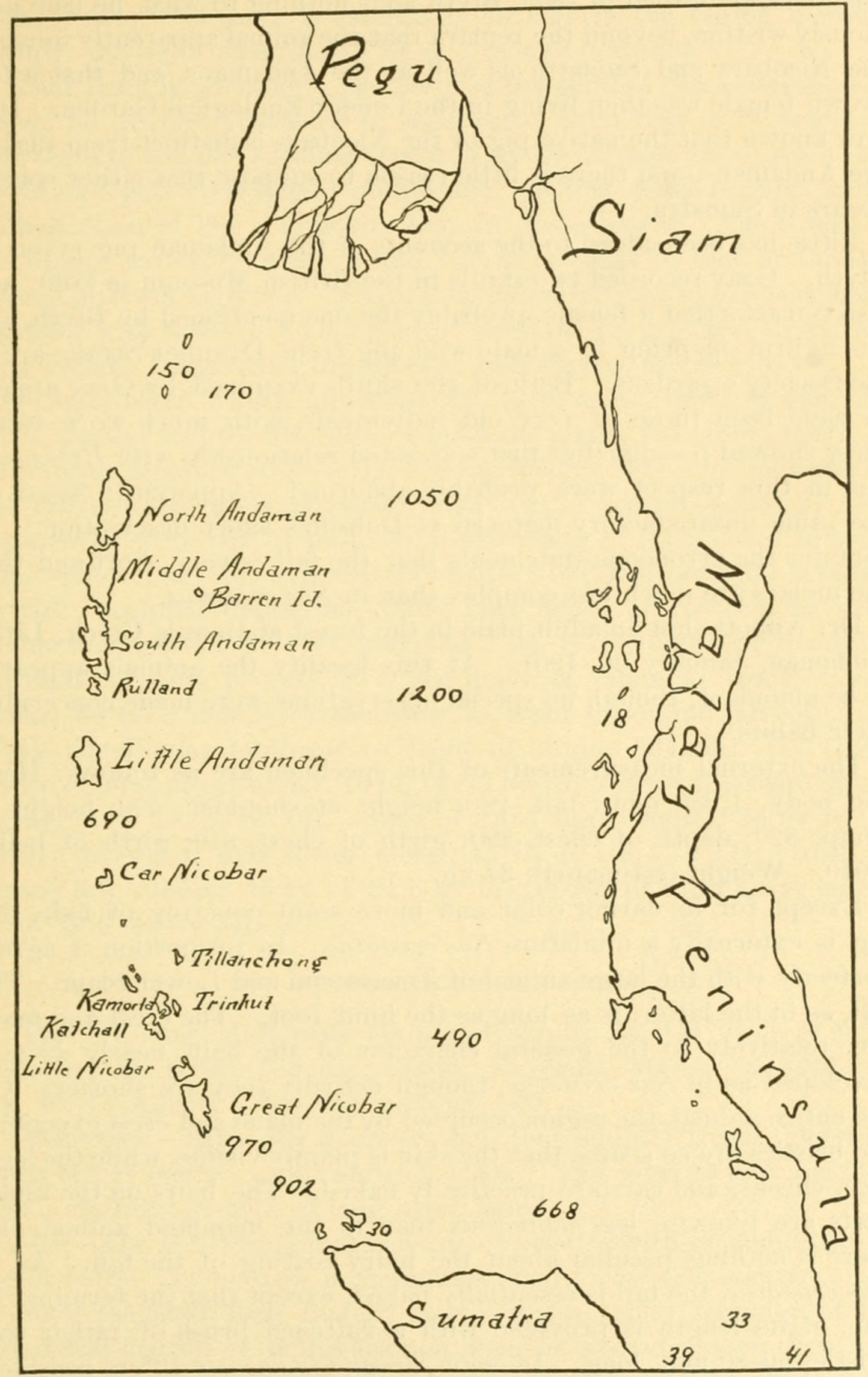

Outline map of the Andaman and Nicobar islands, and neighboring regions.

Proc. N. M. vol. xxiv $-01-48$ 
that this was due to the imperfect condition of his specimen. In the appendix to Mouat's Adventures and Researches among the Andaman Islanders, published in 1863 , Blyth adds nothing to what he had previously written, beyond the remark that the animal apparently inhabits the Nicobars and Sumatra as well as the Andamans, and that a full grown female was then living in the London Zoological Garden. It is now known that the native pig of the Nicobars is distinct from that of the Andamans, and there is little reason to suppose that either species occurs in Sumatra.

Little has been added to the accounts of the Andaman pig given by Blyth. Gray recorded two skulls in the British Museum in $1869,{ }^{1}$ and also remarks that a female, probably the one mentioned by Blyth, and her hybrid offspring by a male wild pig from Dampier Straits are in the Society's gardens. Both of the skulls examined by Gray appear to have been those of very old individuals, with much-worn teeth. They showed peculiarities that suggested relationship with Babirussa, but in this respect were probably abnormal. Apparently based on the same unsatisfactory material is Dobson's short description. ${ }^{2}$ It contains the erroneous statements that the tail is very short and that the molars are much less complex than in Sus cristatus.

Dr. Abbott shot an adult male in the forest at Bumila Creek, Little Andaman, January 20, 1901. At this locality the animals appeared to be abundant, though no special observations were made concerning their habits.

The external measurements of this specimen are as follows: Head and body, 1,030 mm.; tail, 200; height at shoulder, 500; height at rump, 520; depth of chest, 290; girth of chest, 810; girth of belly, 1,040. Weight (estimated), $34 \mathrm{~kg}$.

Except for its darker color and more scant covering of hair, this pig is externally a miniature Sus cristatus. In proportion it agrees perfectly with the large animal of Tenasserim and Lower Siam. The tail, as in the latter, is as long as the hind foot. The crest and mane are, relatively to the general character of the hair, nearly as well developed as in Sus cristatus, though actually they are shorter. On the entire animal, the region occupied by the mane and crest excepted, the bristles are so sparse that the skin is plainly visible, while the legs, face, cheeks, and ears are practically naked. The hairs on the under parts are likewise less numerous than in the mainland animal, but there is nothing peculiar about the hairy coating of the tail. As in Sus cristatus, the tail is essentially naked, except that the terminal 50 $\mathrm{mm}$. of its length is provided with a flattened brush of rather soft bristles 50-80 $\mathrm{mm}$. long. In color Sus andamanensis differs considerably from S. cristatus. The bristles are everywhere clear glossy

\footnotetext{
${ }^{1}$ Catal. Carniv. Pachyderm. and Edentate Mamm. Brit. Mus., pp. 336-337.
}

${ }^{2}$ The Fauna of British India, Mamm., 1891, pp. 562-563. 
black, in certain lights showing faint brownish tips, which become noticeable on the mane and crest only. The caudal tuft is also tinged with brown. As there is essentially no hair in the region it would occupy, the light malar streak of $S$. cristatus is absent.

Aside from its strikingly smaller size the skull of Sus andamanensis shows no distinct character to separate it from that of $S$. cristatus. The teeth of the one specimen secured by Dr. Abbott are so worn that the enamel pattern is largely obliterated, but that which remains shows no indication of less complexity than in Sus cristatus. The length of the hinder molar, both above and below, is equal to that of the two preceding teeth together. The cranial measurements of this specimen, together with those of a young adult skull of Sus cristatus from Tanjong Badak, Tenasserim, the latter in parenthesis, are as follows:

Occipito-nasal length (median), 256 (370) mm.; basal length, 220 (320); basilar length, 215 (310); length of nasals, 123 (185); width of both nasals together posteriorly, 25 (40); median length of bony palate, 153 (220); width of bony palate at middle of second molar, 27 (38); distance between tips of postorbital processes, 81 (111); least interorbital breadth, 55 (85); zygomatic breadth, 114 (148); occipital breadth, 52 (76); occipital depth, 95 (130); least depth of rostrum between canine and incisor, 29 (46); mandible, 190 (270); depth of mandible through coronoid process, $90(120)$; depth of ramus at front of first molar, 36 (47); maxillary toothrow to front of canine (alveoli), 107 (154); mandibular toothrow to front of canine (alveoli), 117 (166); crown of first upper molar, 10 by 14 (17 by 15 ); crown of second upper molar, 17 by 14 (23 by 19); crown of third upper molar, 25 by 16 (37 by 21 ); crown of first lower molar, 13 by 10 (16.4 by 11); crown of second lower molar, 16 by 14 (21.6 by 15$)$; crown of third lower molar, 27 by 13.6 (40 by 17$)$.

\section{SUS NICOBARICUS, new species.}

Type.-Young adult male (skin and skull), No. 111794, U.S.N.M. Collected on Great Nicobar Island, Nicobars, March 13, 1901, by Dr. W. L. Abbott. Original number, 930.

Characters.-Like Sus andamanensis, but slightly larger, and with much larger teeth. Color entirely black. Tail covered with a sparse, nearly uniform growth of long black hairs.

Fur.-The fur throughout consists of bristles with no admixture of softer hairs. In texture it resembles that of Sus andamanensis, and is much less harsh than that of Sus cristatus. The diameter of the individual bristles of both back and mane is scarcely more than half that of hairs from corresponding regions in the mainland animal, and is apparently a little less than in the Andaman pig. Mane and dorsal crest well developed, though less so than in Sus cristatus. At middle of back the bristles of the crest are about $70 \mathrm{~mm}$. in length, while 
those bordering it barely reach a length of $50 \mathrm{~mm}$. The erest, however, owes its distinctness to the greater crowding of the bristles of which it is composed, as compared with those of the surrounding parts. As in Sus andamanensis, the skin is plainly visible through its scant covering of hair everywhere except in the region occupied by the mane and crest. The cheeks are more hairy than in Sus andamanensis. The tail is hairy throughout except at tip. At base the hairs, which are much softer than the bristles of the back, are rather inconspicuous, but near middle they increase in number and in length, and form a straggling brush, the longest hairs of which are $150 \mathrm{~mm}$. long.

Color. - The color is black throughout, with a faint brownish wash on dorsal crest. Hoofs rather dark horn color. In the type the hind feet are albinistic between hoof and hock, the light color involving the hoofs as well as the hair.

Skull.-The skull of Sus nicobaricus, though distinctly larger than that of $S$. andamanensis, shows no approach to the dimensions of that of $S$. cristatus. In form it differs from the skull of Sus andamanensis chiefly in the greater angle formed by the surface of the forehead with that of the rostrum, and in the larger, more inflated audital bullæ. The zygomatic arch as a whole is more heavily built than in Sus andamanensis, and its horizontal surface is broader posteriorly.

As compared with the skull of Sus cristatus from Tenasserim, that of $S$. nicobaricus shows numerou-differences in form. Most conspicuous among these are the relatively shorter rostrum and the very distinct angle in the facial profile at posterior extremity of nasals. This angle is difficult to measure, but it is approximately $8^{\circ}$ in Sus cristatus, and $18^{\circ}$ in S. nicobaricus. The audital bullæ appear to be relatively larger than in the average of Sus cristatus, but this character is probably not constant.

Teeth.-The teeth are slightly larger in proportion to the size of the skull than in Sus andamanensis, but otherwise I can detect no differences. They also agree in all essential characters with those of Sus cristatus.

Measurements. - External measurements of type: Total length, 1,190 mm.; head and body, 1,000; tail, 190; height at shoulder, 520; hind foot (hoof included), 185 .

Cranial measurements of adult male considerably older than type (No. 112011, U.S.N.M.): Occipito-nasal length, 280 (256) mm. ; $^{1}$ basal length, 255 (220); basilar length, 245 (215); length of nasals, 133 (123); width of both nasals together posteriorly, 40 (25); median length of bony palate, 175 (153); width of bony palate at middle of second molar, 31 (27); distance between tips of postorbital processes, 92 (81); least

\footnotetext{
${ }^{1}$ Measurements in parenthesis are those of the slightly older specimen of Sus andamanensis.
} 
interorbital breadth, 71 (55); zygomatic breadth, 130 (114); occipital breadth, 57 (52); occipital depth, 105 (95); least depth of rostrum between canine and incisor, 35 (29); mandible, 220 (190); depth of mandible through coronoid process, 105 (90); depth of ramus at front of first molar, 32 (36); maxillary toothrow to front of canine (alveoli), 118 (107); mandibular toothrow to front of canine (alveoli), 132 (117); crown of first upper molar, 12 by 14 (10 by 14); crown of second upper molar, 17 by 17 (17 by 14); crown of third upper molar, 26 by 18 (25 by 16$)$; crown of first lower molar, _- (13 by 10$)$; crown of second lower molar, 16 by 14 (16 by 14); crown of third lower molar, 30 by 15 (27 by 13.6).

Remarks. - This species is readily distinguishable from the Andaman pig by its larger teeth. The uniform black color of the type and the peculiar hairing of the tail may be mere individual characters.

The occurrence of a diminutive wild pig on the Nicobar Islands was noted as long ago as 1863 by Blyth; ${ }^{1}$ but until the present time there has been no opportunity to compare the animal with Sus andamanensis. That it proves to be distinct from the Andaman swine is not in the least surprising, though such a possibility appears not to have occurred to Blyth. He says:

The small Andamanese wild pig appears, at first, to be as isolated in its range as new to science; but I have been assured of the existence of a diminutive wild pig in the Nicobars, additional to the huge tame swine of undoubtedly exotic origin, which are bred by the Nicobarians of the coasts; and I have also considerable reason to suspect that it exists likewise in Sumatra.

The differences between the wild and domesticated pigs of the Andamans alluded to by Blyth were noted in considerable detail by Dr. Abbott. ${ }^{2}$

Pigs, both tame and wild [he writes] were plentiful in the Nicobars. Those in Kar Nicobar, and many of the tame ones everywhere, are descendents of European and Chinese stock, and splendid big porkers some of them are. But the wild pig of which I send you one skin and two skulls from Great Nicobar does not seem the same. It is small, about the same size as that of Bunguran Island [Sus natunensis], the males weighing abont 90 pounds. I am almost sure that it has been introduced long ago into the Nicobars, and that it was originally Sus cristatus of the mainland, degenerating as the result of insularity and inbreeding. The Danes and others have had settlements on the Nicobars in the last century, and an extensive trade with India and with Chinese junks from Hainan. This trade has been going on for generations, and the modern big pig is the result of the new introductions mixed more or less with the small form. In Great and Little Nicobar many of the tame pigs are precisely like the skin of the wild one which I send, and although the tame animals are usually larger they never equal the size of the huge European pigs of Kar Nicobar and the islands of the central group.

${ }^{1}$ Appendix to Mouat's Adventures and Researches among the Andaman Islanders, p. 349.

${ }^{2}$ Letter dated April 23, 1901. 
Whatever may have been the history of the animal there can be little doubt that it is now a distinct species. I am inclined to believe that it was introduced by human agency, but at a time far anterior to the establishment of European trade.

\section{Genus MUS Linnæus.}

Three species of Mus have been recorded from the Andaman Islands, Mus musculus and Mus andamanensis by Blyth, and Mus bowersi by Blanford. Only the second of these was certainly obtained by Dr. Abbott, though it is probable that the animal here described as Mus taciturnus is the Mus boversi of Blanford. From the Nicobars the only rat hitherto known is the Mus palmamum of Zelebor. This was regarded by Blanford as identical with Mus rattus. Dr. Abbott did not meet with it. On the other hand he secured six species in the Andamans and five in the Nicobars, raising the total number known from the islands to twelve. These may be distinguished by the following characters:

KEY TO THE SPECIES OF MUS KNOWN TO OCCUR ON THE ANDAMAN AND NICOBAR ISLANDS.

Total length of adult less than $300 \mathrm{~mm}$.............................. musculus Total length of adult more than $300 \mathrm{~mm}$.

Greatest length of skull about $55 \mathrm{~mm}$.

Underparts yellowish white ...................... Mus palmarum

Underparts brownish gray or bluish gray.

Underparts strongly tinged with yellow.............. Mus taciturnus

Underparts slightly tinged with yellow ................. Mus stoicus

Greatest length of skull less than $50 \mathrm{~mm}$.

Fur distinctly spiny.

Hind foot about $40 \mathrm{~mm}$................................ Mus flebilis

Hind foot distinctly less than $40 \mathrm{~mm}$.

Underparts whitish; skull with dorsal outline strongly convex.

Mus andamanensis

Underparts brown; skull with dorsal outline nearly straight.

Mus pulliventer

Fur soft.

Back conspicuously blackish......................... atratus

Back not blackish.

Hind foot $40 \mathrm{~mm}$. or more.

Nasal bones abruptly constricted near middle... Mus burrescens

Nasal bones not abruptly consticted near middle .. Mus burrus Hind foot distinctly less than $40 \mathrm{~mm}$.

Back strongly tinged with dull red ............ Mus burrulus

Back yellowish brown.

Color of belly sharply defined, teeth robust.

Mus andamanensis

Color of belly merging into that of sides; teeth weak. 


\section{MUS MUSCULUS Linnæus.}

1859. Mus manei Blyth, Journ. Asiat. Soc. Bengal, XXVIII, p. 271.

The house mouse was recorded from the Andamans by Blyth. The specimens to which he referred were taken at Port Blair. The animal is apparently unknown in the Nicobars.

\section{MUS PAI.MARUM Zelebor.}

1861. Mus palmarum (adult) and Mus novaræ (immature) Fitzinger, Sitzungsber. Math.-Naturwissensch. Cl. Kais. Akad. Wissensch., Wien, XLII (1860), pp. 385, 394. 1861. (Nomina nuda.)

1869. Mus palmarum Zelebor, Reise der österreichischen Fregatte Novara, Zool., I (Wirbelthiere), 1, Mamm., p. 26. (Nicobar Islands.)

The very clear and detailed description of this rat leaves no doubt that the animal is distinct from Mus rattus and somewhat closely allied to the large Mus stoicus and Mus taciturnus of the Andamans. Its dimensions alone are sufficient to separate it from the black rat and allied forms. Some of the measurements are as follows: Head and body, $275 \mathrm{~mm}$.; tail, 215 ; hind foot, 50; greatest length of skull, 54; greatest breadth of skull, 25 . In the members of the group to which the black rat belongs the hind foot seldom reaches a length of $40 \mathrm{~mm}$., and the greatest length of skull is rarely over $45 \mathrm{~mm}$. The pattern of enamel folding in the molar teeth of Mus palmarum apparently differs in several important particulars from that of Mus rattus and its allies; but the animals are too distinct to require detailed comparison.

The palm rat is said by Zelebor to be not uncommon in the Nicobar Islands, where it occurs mostly in the crowns of the palms, leaping from tree to tree with much agility. It was not met with by Dr. Abbott.

MUS STOICUS, new species.

Type.-Adult male (skin and skull) No. 111834, U.S.N.M. Collected on Henry Lawrence Island, Andamans, January 9, 1901, by Dr. W. L. Abbott. Original number, 820.

Characters. - A large, heavily built rat, bearing a general likeness to Mus validus and Mus palmarum. Tail considerably shorter than head and body, unicolor. Fur of back moderately spinous. Underparts bluish gray. Mammæ apparently ten. Skull as long as that of Mus validus, but very slender. Teeth with normal enamel pattern, the length of upper molar series (alveoli) in adults less than half diastema.

Fur.-Underfur rather scant, much less dense than in Mus validus or Mus norvegicus, but not peculiar in quality; it is most abundant on flanks and lumbar region. Main body of fur composed of two elements, soft terete hairs and stiff grooved bristles. On middle of back these are about $15 \mathrm{~mm}$. in length, but the hairs usually a little exceed the bristles. Width of bristles on back about $.33 \mathrm{~mm}$. On underparts they become much more slender and are scarcely to be distin- 
guished from the terete hairs. The bristles are numerous on middle of back and on sides, but are practically absent from rump and from region in front of shoulders. The back is rather plentifully sprinkled with coarse terete hairs about $50 \mathrm{~mm}$. in length, but these are not sufficiently numerous to influence the general appearance of the fur. Whiskers coarse, the longest $70 \mathrm{~mm}$. in length. Supraorbital bristle about $10 \mathrm{~mm}$. less.

Color. - Back a coarse grizzle of black and dull ochraceous buff (distinctly darker than Ridgway's Pl. v, fig. 10) the latter element in excess. The effect is similar to the general color of Mus validus but considerably more yellow. The longer hairs are strongly lustrous, so that in certain lights the fur has a noticeable steely gloss. This sheen is very conspicuous at sides of shoulders when the skin is viewed from in front. Sides like back but with buff even more predominant. Underparts and inner surface of limbs nearly uniform mouse gray (paler than that of Ridgway). This color is due to the combined effect of the drab underfur and whitish hair tips. It extends entirely around upper lip and spreads over cheeks, where, however, it becomes mixed with ochraceous buff. Eye surrounded by a very faintly indicated dark ring. Whiskers black. Ears and tail uniform dull dark brown throughout. Feet sprinkled with fine whitish hairs, these nowhere abundant enough to conceal the light brown skin.

Tail. - The tail is rather inconspicuously annulated-that is, the boundaries of the scales are less sharply defined than in most rats of the same size. At middle there are about 10 rings to the centimeter. At first sight the tail appears to be naked, but on close inspection it is seen to be beset with fine appressed hairs 1 to $2 \mathrm{~mm}$. in length, two or three of which spring from the base of each scale.

Mamma. - In the single adult female collected one pectoral and three inguinal mammæ are plainly visible on each side. The skin is in bad condition in the region which the anterior pair of pectoral mammæ would occupy if present. On the label Dr. Abbott has written " mammæ apparently ten.'

Feet.-The feet show no peculiarities of form or structure. Soles naked, with six well-developed tubercles.

Ears. - The ears are moderately large, their height from crown exactly equal to distance between eye and tip of muzzle. In form they are not peculiar. Both surfaces are naked except for a fine, close pubescence.

Skull. - The skull of Mus stoicus differs conspicuously from that of Mus validus, Mus vociferans, or Mus bowersi in its much lighter structure and more slender form. Viewed from above it does not differ widely from the skull of Mus vociferans, except that it is more narrow throughout, a difference more noticeable in rostrum and braincase than in the zygomatic region. Supraorbital ridges about as in Mus vociferans. The plate of the maxillary forming outer wall of 
antorbital foramen is as broad as in Mus validus, but the foramen is widely open below, as in Mus vociferans. These characters are very apparent in this view of the skull. Viewed from the side the skull closely resembles that of Mus vociferans, except for the peculiarities already mentioned. Zygomata much more slender than in the allied species. Viewed from beneath the skull shows its most striking characters. The floor of the braincase is essentially like that of Mus vociferans, though the audital bullæ are distinctly larger than in the mainland animal. In form the bullæ do not differ very materially from those of Mus vociferans, though they are somewhat more inflated anteriorly. Palate and rostrum very unlike those of any of the allied species, the differences due to the combined reduction in size of the teeth and elongation of rostrum. The length of toothrow is contained fully twice in length of diastema, instead of about once and a half, as in Mus vociferans and Mus validus. The incisive foramina share in the elongation of the rostrum to such an extent that they are much longer than the toothrow instead of distinctly shorter. Except that it shares in the general slender form of the skull the mandible shows no characters of importance.

Teeth. - The teeth differ from those of Mus vociferans in size only, as the enamel pattern of the two species is similar throughout.

Measurements.-External measurements of type: Total length, 442 mm.; head and body, 249; tail, 193; hind foot, 47 (45); ear from meatus, 24; ear from crown, 20; width of ear, 16. Average of ten adults from the type locality: Total length, 437 (415-465); head and body, 241 (220-260); tail, 198 (192-212); hind foot, 48 (47-50); hind foot without claws, $46(45-48)$. For detailed measurements see table, page 764 .

Cranial measurements of largest specimen: Greatest length, $55.4 \mathrm{~mm}$. $(56) ;^{1}$ basal length, 50 (47.6); basilar length, 47 (44.6); palatal length, 28 (25); least width of palate between anterior molars, $6(5)$; diastema, 18 (14.8); length of incisive foramen, 10.6 (8); combined breadth of incisive foramina, 3.8 (3.8); length of nasals, 22 (21.4); combined breadth of nasals, $5.4(6.2)$; zygomatic breadth, 25 (25.8); interorbital breadth, 9 (9); breadth of braincase above roots of zygomata, 18 (20.4); mastoid breadth, 19 (18.8); occipital depth at front of basioccipital, 14.6 (14); frontopalatal depth at posterior extremity of nasals, 13 (13.6); least depth of rostrum immediately behind incisors, 9.8 (11); mandible, $31(30.6)$; maxillary toothrow (alveoli), 8.2 (11.8); width of front upper molar, 2.4 (3); mandibular toothrow (alveoli), 8.4 (10).

Specimens examined.-Eighteen, all from the type locality.

Remarks.-In general appearance Mus stoicus resembles Mus validus, but the skull is much more slender. It is, however, in no way distantly related to the large rats of the Malay Peninsula.

${ }^{1}$ Measurements in parenthesis are those of the type of Mus rocterans. 
Dr. Abbott writes as follows of the rats of Henry Lawrence Island (Mus stoicus and Mus flebilis):

Trapped in the dense jungle with which the island is covered. Note that in this lot there are two distinct species; one large with tail shorter than head and body [M. stoicus], and one smaller with tail longer than head and body [M. Alebilis]. The tail is more hairy in the smaller species. Both were caught in the same places, on the west side of the island on Kwantung Straits, at two localities about two miles apart. The smaller one squeals piteously when caught in a trap, but the larger is silent.

\section{MUS TACITURNUS, new species.}

Type.-Adult male (skin and skull), No. 111828, U.S.N.M. Collected on South Andaman Island, Andamans, January 16, 1901, by Dr. W. L. Abbott. Original number, 854 .

Charcacters. - Slightly larger than Mus stoicus, and color both above and below more tinged with yellow.

Color. - Back and sides a coarse grizzle of black and bright ochraceous buff (distinctly more yellow than Ridgway's, Pl. v, fig. 10), the latter very conspicuously in excess. Underparts paler than in Mus stoicus, though the elements of the color are essentially the same, the difference due to the more extensive whitish hair tips, and faintly lighter under fur. Color otherwise as in Mus stoicus.

Measurements. - External measurements of type: Total length, 494 mm.; head and body, 266; tail, 228; hind foot, $53(50)$; ear from meatus, 24; ear from crown, 21; width of ear, 16.4. An adult female measures: Total length, 446; head and body, 237; tail, 209; hind foot, 48 (46). For detailed measurements see table, page 764 .

Specimens examined.-Seven, all from the type locality.

Remarks. - This species is very closely allied to Mus stoicus, but is nevertheless easily distinguishable on comparison. It is probably the rat recorded by Blanford as "a variety of Mus bowersi or a closely allied form." ${ }^{1}$ Mus bowersi differs, however, from all of the rats known to occur on the Andamans by its distinctly bicolored tail.

MUS FLEBILIS, new species.

Type.-Adult female (skin and skull), No. 111841, U.S.N.M. Collected on Henry Lawrence Island, Andamans, January 10, 1901, by Dr. W. L. Abbott. Original number, 827.

Characters. - A large member of the Mus rattus group. Size about as in Mus pannosus of the Butang Islands, but tail always considerably longer than head and body. Fur thickly sprinkled with weak spines, its color paler and more yellow than in Mus pannosus and closely resembiing that of Mus stoicus. Skull much like that of Mus pannosus, but with larger audital bullæ, more prominent supraorbital ridges, and smaller teeth. 
Fur.-The fur is like that of Mus stoicus, except that the bristles are a little less stiff and the under fur is somewhat more woolly. The long terete hairs on the back are less noticeable than in the larger animal. In abundance and distribution the bristles are essentially the same in the two species.

Color.-Back and sides essentially as in Mus stoicus, except that the light element of the grizzle is paler, almost exactly matching the vochraceous buff of Ridgway, and a little more noticeably in excess of the dark. The fur is nearly destitute of the lustrous sheen so noticeable in the larger animal. Muzzle and outer surface of front legs washed with broccoli-brown. Under parts and inner surface of limbs cream buff. Under fur light drab. Ears and tail dull brown throughout. The color of the under parts completely encircles the mouth, but scarcely spreads upward on cheeks. Feet more thickly haired than in Mus stoicus, cream buff heavily clouded with drab. Whiskers black. A faintly indicated dark eye-ring.

Tail.-The annulation of the tail is similar to that in Mus stoicus, except that the rings and scales are more sharply defined. At middle there are 10 rings to the centimeter. The hairs, though not conspicuous, are longer and more abundant than in the larger animal.

Mammce.-There are 10 mammæ, 2 pectoral and 3 inguinal on each side.

Feet.-The feet are in no way peculiar. Soles naked, with 6 welldeveloped tubercles.

Ears.-The ears are essentially as in Mus stoicus.

Skull.-The skull of Mus flebilis resembles that of the larger members of the Mus rattus group, but is readily distinguishable by its larger audital bullæ and more strongly developed supraorbital ridges. In the latter character it suggests Mus surifer and its allies. As compared with the skull of Mus pannosus that of Mus flebilis differs, aside from the characters just mentioned, in slightly smaller size, relatively shorter, more robust rostrum, narrower outer wall of antorbital foramen, more abruptly flaring zygomata, and longer incisive foramina. The mandible is essentially the same in both species. Its much greater size (greatest length about $45 \mathrm{~mm}$. instead of about 40 ) immiediately distinguishes the skull of Mus flebilis from that of Mus rattus and Mus alexandrinus.

Teeth.-The teeth exactly resemble those of Mus alexandrinus and Mus rattus in form and in pattern of enamel folding, but are conspicuously larger. In the latter character they are slightly surpassed by those of Mus pannosus.

Measurements.-External measurements of type: Total length, 452 mm.; head and body, 210; tail, 242; hindfoot, 41.4 (39); ear from meatus, 21; ear from crown, 16; width of ear, 15. Average of 6 adults from the type locality: Total length, $441(417-460)$; head and 
body, 203 (193-210); tail, 238 (222-240); hindfoot, 41.8 (41-44); hindfoot without claws, 40 (39-42). For detailed measurements see table below.

Cranial measurements of type: Greatest length, $45(47.6)^{1} \mathrm{~mm}$; basal length, 40 (41); basilar length, 37 (37.6); palatal length, 21.4 (22); least width of palate between anterior molars, 5 (5); diastema, 13 (13); length of incisive foramen, $8.8(8)$; combined breadth of incisive foramina, 3 (4); length of nasals, 18 (18); combined breadth of nasals, 4.8 (5.4); zygomatic breadth, 19.8 (22); interorbital breadth, 6 (7); mastoid breadth, 18 (18); breadth of braincase above roots of zygomata, 16 (16.4); depth of braincase at anterior border of basioccipital, 11.4 (12); fronto-palatal depth at posterior extremity of nasals, 11 (11.4); least depth of rostrum immediately behind incisors, 8.6 (9); mandible, 26 (27.6); maxillary toothrow (alveoli), 7.4 (8); width of front upper molar, 2.2 (2.6); mandibular toothrow (alveoli), 7.4 (7.8).

Specimens examined. - Seven, all from the type locality.

Remarks. - These rats were trapped, together with the specimens of Mus stoicus, in the dense jungle with which Henry Lawrence Island is covered. The.types of both species were taken on the south side of the island on the shore of Kwantung Straits. Other specimens were secured at a point about 2 miles farther north. The names which I have used for the two species were suggested by Dr. Abbott's note that the smaller animal squeals piteously when caught, while the larger is silent.

Table of measurements of Mus stoicus, Mus taciturnus, and Mus flebilis.

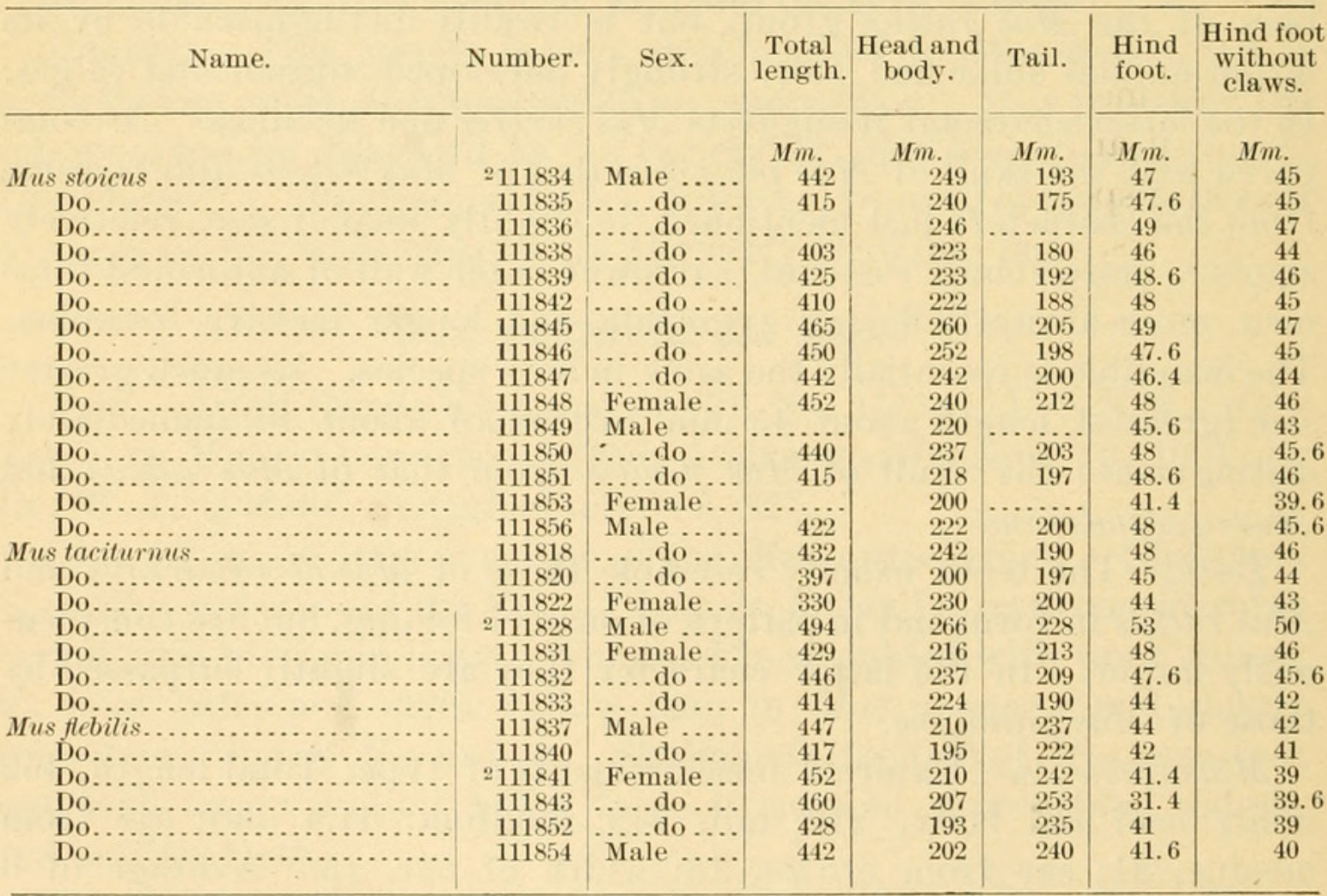


MUS ANDAMANENSIS Blyth.

Mus (Leggada?) andamansis BLyth, Journ. Asiat. Soc. Bengal, XXIX, 1860, p. 103. (Port Blair, South Andaman Island.)

Blyth first mentioned the Andaman rat in $1859^{1}$ as a species " not of recent introduction," to the islands. The following year specimens taken by Captain Hodge, then in command of the guard ship Sesostris at Port Blair, enabled him to name and describe the animal. Though occasionally alluded to during the course of the next few years ${ }^{2}$ Mus andamanensis has remained a very imperfectly known animal, and since $1891^{3}$ has been generally regarded as identical with Mus rattus.

Dr. Abbott secured eight specimens at MacPherson Strait, South Andaman Island. These show that the species is quite distinct from Mus rattus, Mus alexandrinus, or any other known rat. It may be characterized as follows:

In size and external appearance much like the form of Mus alexandrinus, occurring in Trong, Lower Siam, and on Nankauri Island, Nicobars, but fur often, though not invariably, more spinous, and light color (pale cream buff) of under parts sharply contrasted with brown of sides. Tail slightly longer than head and body. Skull similar to that of Mus alexandrinus, but teeth noticeably larger.

There is considerable variation in the quality of the fur. In six of the specimens the spines are larger and much more conspicuous than in Mus alexandrinus, but in the others they are exactly as in the mainland animal. Color as in Malayan Mus alexandrinus, except that there is a distinct line of demarcation between the pale cream buff of the belly and the yellowish brown of the sides. As shown by the table of measurements (page 772), the tail is usually a little longer than the head and body. The single exception (No. 111823) is so striking that the specimen suggests at first sight a distinct species; but in all characters, except the greatly elongated tail, it agrees with the others from the same locality.

MUS PULLIVENTER, new species.

Type--Adult male (skin and skull), No. 111790, U.S.N.M. Collected on Great Nicobar Island, Nicobars, March 12, 1901, by Dr. W. L. Abbott. Original number, 927.

Characters. - A rat of somewhat less bulk than Mus flebilis, but with smaller hind foot and shorter tail, the length of latter considerably less than that of head and body. Fur densely spinous, but the bristles even more slender than in Mus flebilis. Color brown throughout, the belly not distinctly paler than sides, skull slender, with dorsal profile

${ }^{1}$ Journ. Asiat. Soc. Bengal, XXVIII, p. 27.

${ }^{2}$ Blyth, Appendix to Mouat's Adventures and Researches among the Andaman Islanders, 1863 , p. 354 .

${ }^{3}$ Blanford, The Fauna of British India, Mamm., p. 406. 
nearly straight from middle of brain case to tip of nasals. Teeth small, normal. Mammæ 8.

Fur. - The fur is fine and close in texture, but on examination it is seen to be densely beset with very slender spines. These spines are rather more numerous than in Mus flebilis, but their width is distinctly less than in the Andaman species. The fur of the back is sprinkled with a few long terete hairs, but these are only evident on close inspection. On the belly the bristles are reduced to mere rudiments scarcely to be distinguished from the ordinary hairs.

Color.-Back and sides a fine grizzle of black and russet, the two colors in about equal parts on the back, the russet in excess on the sides and outer surface of legs, where it is faintly washed with wood brown. Belly and inner side of legs drab, a little tinged with russet. Chin, middle of throat, axillary region and area surrounding nipples white, this color perhaps abnormal. Cheeks and muzzle like belly, but slightly more washed with russet. Top of head dark, grizzled hair brown. Feet scantily sprinkled with brownish and whitish hairs. Ears and tail uniform dark brown.

Tail. - The annulation of the tail is indistinct and somewhat irregular. At middle there are eleven or twelve rings to the centimeter. From the base of each scale spring two or three stiff hairs, the length of which scarcely exceeds the width of the rings. The hairs are very inconspicuous, and more apparent to the touch than to sight. At extreme tip the skin of the tail is whitish, but this character may readily be abnormal.

Mamma.-There are 8 mammæ, 1 pectoral pair and 3 inguinal pairs.

Feet.-Relatively to the size of the animal, the feet are unusually small and weak. Soles with the six pads rather indistinct in the dry specimen.

Ears. - The ears are in no way peculiar. In length they are about equal to distance between eye and muzzle. They are naked, except for a fine, almost microscopic pubescence.

Skull. - The skull of Mus pulliventer differs conspicuously from that of the other Andaman and Nicobar rats in its flat dorsal outline. When viewed from the side the profile is nearly straight from front of nasals to middle of braincase. The palatal profile shares the same peculiarity but to a less degree. Except for its flatness the skull closely resembles that of Mus rattus. The rostrum is, however, more elongate, and the audital bullæ are smaller. When viewed from above the plate forming outer wall of antorbital foramen scarcely extends in front of line of outer curve of zygomatic arch, while in Mus rattus it projects conspicuously in front of this line. Viewed from the side this plate is narrower and less concave than in Mus rattus, and its front edge is nearly straight. 
Teeth.-The teeth of the type are somewhat worn, but they appear to be in every way similar to those of Mus rattus.

Measurements. - External measurements of type: Total length, 387 mm.; head and body, 202; tail, 185; hind foot, 35 (33); ear from meatus, 19; ear from crown, 14; width of ear, 15.

Cranial measurements of type: Greatest length, $44 \mathrm{~mm}$; basal length, 40; basilar length, 38; palatal length, 22.6; least width of palate between anterior molars, 4.6 ; diastema, 12.6 ; length of incisive foramen, 7.8 ; combined breadth of incisive foramina, 4 ; length of nasals, 16 ; combined breadth of nasals, 4.6 ; zygomatic breadth, 21.8; interorbital breadth, 6.4 ; breadth of braincase above roots of zygomata, 16.2; mastoid breadth, 16.8; occipital depth at front of basioccipital, 13; frontopalatal depth at posterior extremity of nasals, 9.6; least depth of rostrum immediately behind incisors, 7.6 ; mandible, 25; maxillary toothrow (alveoli), 7.8; width of front upper molar, 2; mandibular toothrow (alveoli), 6.8.

Specimens examined.-One, the type.

Remarks.-Mus pulliventer differs so conspicuously from its allies of the Mus rattus group that it needs no special comparison with any of them. The flattened skull and dark color of the under parts are sharply diagnostic.

MUS ATRATUS, new species.

Type--Adult female (skin and skull), U.S.N.M. No. 111868, Collected on Barren Island, Andamans, January 7, 1901, by Dr. W. L. Abbott. Original number, 818.

Characters. - Size and proportions as in Mus andamanensis, but fur spineless. Color of under parts yellowish brown, back strongly suffused with black (often entirely black). Skull shorter, broader, and more robust than that of Mus andamanensis, the audital bullæ smaller. Teeth as in Mus andamanensis and Mus rattus, but much larger.

Fur.-The fur consists of the usual elements. The spines, however, are so reduced in diameter as to appear like ordinary hairs unless examined with a lens.

Color.-Upperparts almost exactly as in Mus Alebilis and Mus andamanensis, except that the fur is strongly suffused with a slaty black like that of Mus rattus. In two of the eight specimens the brown remains in excess of the black, but in the others (including the type) the latter predominates, nearly or quite to the exclusion of the brown. Belly yellowish brown (rather paler and less yellow than the ochraceous buff of Ridgway) in the brown-backed specimens, slaty in the others. Only one skin, however, lacks a distinct brownish wash over the slaty under parts. Feet sprinkled with whitish or slaty hairs. Ears and tail uniform dark brown. 
Tail. - The tail is distinctly annulated. At middle there are about ten rings to the centimeter. The boundaries of the scales are sharply defined, much more so than in Mus stoicus and Mus flebilis. From the base of each scale grow three hairs which in length are equal to the width of two rings. Though better developed than in the larger Andaman rats, these hairs do not conceal the annulation of the tail.

Feet.-The feet are in no way peculiar. Soles naked, 6 -tuberculate.

Ears. - The ears are of moderate length, about equal to distance between eye and nostril. They are naked except for a fine, inconspicuous pubescence.

Skull.-The skull is much like that of Mus rattus, except that the frontal profile is more strongly concave, the audital bullæ are smaller, and the region between and including anterior zygomatic roots is broader and more heavily built. The incisive foramina extend back nearly to level of middle of first molar.

Teeth.-The teeth are similar to those of Mus rattus but very much larger.

Measurements.-External measurements of type: Total length, 342 $\mathrm{mm}$; head and body, 160; tail, 182; hind foot, 36 (34); ear from meatus, 18; ear from crown, 14; width of ear, 13 . Average of seven adults from the type locality: Total length, 353 (342-372); head and body, 175 (160-195); tail, 181 (173-190); hind foot, 39.7 (39-41.6); hind foot without claws, $37.3(36-39)$. For detailed measurements see table, page 772 .

Specimens examined.-Eight, all from the type locality.

Remarks.-In the appendix to Mouat's Adventures and Researches among the Andaman Islanders Blyth remarks that-

lately the Rev. C. S. P. Parish, the able botanist and chaplain of Moulmein, observed on Barren Island the half-devoured remains of some rat, which it is not likely had been carried by a bird of prey from the nearest land, 36 miles distant. As the carcass was much mutilated, Mr. Parish did not think it worth while to preserve it in spirits, though had he done so the identification of the species, with the peculiar spiny-coated Mus andamanensis, would probably have been easy.

This is the only published allusion to the Barren Island rat that I have seen.

Dr. Abbott found the animal excessively abundant in favorable localities among the patches of grass and scrubby jungle with which the volcanic ash and scoria of Barren Island are covered. He noted nothing peculiar in its habits.

MUS BURRUS, new species.

Type.-Adult female (skin and skull), No. 111811, U. S. N. M. Collected on Trinkut Island, Nicobars, February 5, 1901, by Dr. W. L. Abbott. Original number, 881 . 
Characters. - Size and general appearance much as in Mus pulliventer, but tail shorter, back less distinctly grizzled, and belly light buff. Fur spineless. Mammæ 10. Skull much like that of Mus norvegicus. Fur. - The fur is like that of Mus atratus, that is, the spines are so reduced in diameter that on casual examination they do not appear different from the surrounding hairs. They are, however, slightly larger than in Mus atratus.

Color.-Back and sides a fine grizzle of black and russet, the colors nearly as in Mus pulliventer, but grizzle less distinct. The two elements are in about equal parts on back, but on sides the russet is considerably in excess of the black, and at the same time slightly obscured by the drab gray of the underfur. Under parts and inner side of legs cream-buff to base of hairs. Crown and forehead like back, but a little tinged with gray; cheeks washed with drab. Feet scantily clothed with whitish and brownish hairs. Ears and tail uniform dark brown.

Tail. - The tail is coarsely and distinctly annulated. At middle there are about eight rings to the centimeter. To each scale there are from one to three stiff hairs varying in length from 1 to $1 \frac{1}{2}$ millimeters. Mamma.-There are ten mammæ, four pectoral and six inguinal.

Feet.-The feet are in no way peculiar. Soles naked, with the usual six tubercles.

Ears.-Ears as in the related species.

Skull. - In a general way the skull of Mus burrus rather closely resembles that of Mus norvegicus. It is slightly smaller than that of the house rat, however, the dorsal profile is less convex, the rostrum shorter and broader, the interorbital region less constricted, the zygomatic arches less flaring, the braincase broader and less elevated, the interpterygoid space wider, and the audital bullæ slightly different in form and more resembling those of Mus rattus. Nasal bones gradually narrowed from front to back, their outer margins nearly straight except for the usual slight downward curve. Posterior portion of mandible somewhat deeper than in Mus norvegicus.

Teeth.-The teeth are relatively somewhat larger than in the house rat, but the enamel pattern shows no peculiarities.

Measurements.-External measurements of type: Total length, 430 mm.; head and body, 215; tail, 215; hind foot, 43 (41); ear from meatus, 24; ear from crown, 18; width of ear, 17. Average of ten specimens from the type locality: Total length, 407 (385-430); head and body, 205 (195-225); tail vertebræ, 202 (193-215); hind foot, 42.5 (42-43); hind foot, without claws, 40.6 (40-41.4). For detailed measurements, see table, page 772 .

Cranial measurements of type: Greatest length, $47.6 \mathrm{~mm}$. (49) ${ }^{1}$; basal length, 43 (43.6); basilar length, 40 (41); palatal length, 23.4 (23); least width of palate between anterior molars, 5.4 (5); diastema, 14 (14);

${ }^{1}$ Measurements in parenthesis are those of an adult female Mus norvegicus.

Proc. N. M. vol. xxiv $-01-49$ 
length of incisive foramen, 8.4 (8.4); combined breadth of incisive foramina, 2.8 (3.8); length of nasals, 17.4 (18.6); combined breadth of nasals, 5 (5); zygomatic breadth, 22 (25); interorbital breadth, 8 (7); mastoid breadth, 17.4 (19); breadth of braincase above roots of zygomata, 17 (16.8); depth of braincase at anterior border of basioccipital, 12.2 (13.6); fronto-palatal depth at posterior extremity of nasals, 11.8 (11); least depth of rostrum immediately behind incisors, 9 (9); mandible, 28 (29); maxillary toothrow (alveoli), 7.6 (7.4); mandibular toothrow (alveoli), 7.4 (7).

Specimens examined.--Twelve, all from Trinkut Island, Nicobar's.

Remarks. - In external characters, the series of twelve skins show practically no variation. The younger specimens are less clear buff beneath, but with this exception the color is perfectly constant. The skulls are likewise very uniform. Here the variation is confined to the slight differences in size usually correlated with greater or less age. The nearly straight lateral outline of the nasal is an unvarying characteristic of the entire series of skulls.

Whether Mus burrus is a direct descendant of the house rat can not be decided, but its relationship with this wandering species is not remote. The dark color and less spreading zygomata are alone sufficient to distinguish the Nicobarean animal, however, from any of the very numerous specimens of Mus norvegicus that have come under my observation.

MUS BURRULUS, new species.

Type.-Adult male (skin and skull), No. 111817, U. S. N. M. Collected on Car Nicobar, January 25, 1901, by Dr. W. L. Abbott. Original number, 865 .

Characters.-Similar to Mus burrus, but much smaller; hind foot, 38 (36); greatest length of skull, 41.

Color.-The color and other external characters so closely resemble those of Mus burrus as to need no detailed description.

Skull.-The skull though differing from that of Mus burrus chiefly in its smaller size is also distinguishable by its much more slender rostrum, a character which is in no way due to differences of age. The outer margin of the nasal is straight, as in the larger animal.

Teeth.-The teeth are similar to those of Mus burrus, though perceptibly smaller throughout.

Measurements.-External measurements of type: Total length, 357 mm.; head and body, 174; tail, 183; hind foot, 38 (36); ear from meatus, 19; ear from crown, 15; width of ear, 15.

Cranial measurements of type: Greatest length, $41 \mathrm{~mm}$; basal length, 37.4; basilar length, 34.8; length of nasals, 15 ; combined breadth of nasals, 4; zygomatic breadth, 19.8; interorbital constriction, 6.8; maxillary toothrow (alveoli), 7 . 
Specimens examined.-One, the type.

Remarks.-Although represented by only one specimen the rat of isolated Car Nicobar is evidently distinct from those of the larger southern islands. That its small size is not due to immaturity is shown by the fact that the type is fully adult, with distinctly worn teeth, a much older individual than several of the specimens of Mus burrus.

MUS BURRESCENS, new species.

Type--Adult female (skin and skull), No. 111789, U.S.N.M. Collected on Great Nicobar Island March 12, 1901, by Dr. W. L. Abbott. Original number, 926.

Characters. - Externally similar to Mus burrus, but red of upper parts a little more intense. Skull distinguishable from that of the related species by the form of the nasal bones, which are strongly contracted a little in front of middle.

Color.-The upper parts are slightly more red than in Mus burrus and the grizzle produced by the black hair-tips is less coarse, differences easily appreciable on comparison. Otherwise the two animals are entirely similar so far as external characters are concerned.

Skull.-The skull is like that of Mus burrus except in the form of the nasal bones. The outer margin of each nasal, straight or nearly so in Mus burrus, is here abruptly concave at middle. The result is a spatulate outline of the two nasals together, quite different from the regular cuneate form characteristic of Mus burrus and Mus burrulus.

Teeth.-Teeth as in Mus burrus.

Measurements. - External measurements of type: Total length, 408 mm.; head and body, 206; tail, 202; hind foot, 40 (38); ear from meatus, 21; ear from crown, 16; width of ear, 15.

Cranial measurements of type: Greatest length, $44.6 \mathrm{~mm}$; basal length, 40; basilar length, 38; length of nasals, 16 ; combined breadth of nasals, 5.6; zygomatic breadth, 21.8; interorbital constriction, 6.8; maxillary toothrow (alveoli), 7.4.

Specimens examined.-Two, both from Great Nicobar Island. A specimen from Little Nicobar may represent this species, but it is too young for positive determination.

Remarks.-The cranial character by which this species is distinguished from its allies though trivial is apparently of perfect constancy. In none of the twelve skulls of Mus burrus is there any approach to the spatulate form of nasals. 
Table of measurements of Mus andamanensis, Mus atratus, and Mus burrus.

\begin{tabular}{|c|c|c|c|c|c|c|c|}
\hline Name. & Number. & Sex. & $\begin{array}{c}\text { Total } \\
\text { length. }\end{array}$ & $\begin{array}{c}\text { Head and } \\
\text { body. }\end{array}$ & Tail. & $\begin{array}{l}\text { Hind } \\
\text { foot. }\end{array}$ & $\begin{array}{l}\text { Hind foot } \\
\text { without } \\
\text { claws. }\end{array}$ \\
\hline Mus andamanensis & 111821 & Male & ${ }_{375}$. & $\mathrm{Mm}_{183}$ & $\underset{192}{M m .}$ & $\underset{39}{\mathrm{Mm}}$. & $\mathrm{Mm}$. \\
\hline 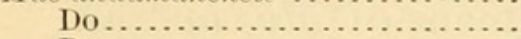 & 111823 & ..... do ... & 387 & 175 & 212 & 38 & $\begin{array}{l}37.6 \\
36.6\end{array}$ \\
\hline 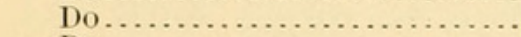 & 111824 & Female... & 297 & 160 & 137 & 37 & 36 \\
\hline Do.............. & 111826 & Male .. & 360 & 176 & 184 & 37 & 35.6 \\
\hline Do $\ldots \ldots \ldots \ldots$ & 111827 & Female. & 363 & 182 & 181 & 37 & 35 \\
\hline Do $\ldots \ldots \ldots \ldots$. & 111829 & Male ..... & 378 & 188 & 190 & 37 & 36 \\
\hline Do $\ldots \ldots \ldots \ldots \ldots$ & 111952 & ..... do ... & 365 & 179 & 186 & 37 & 36 \\
\hline Do $\ldots \ldots \ldots \ldots$ & 111953 & Female.. & 365 & 175 & 190 & 37.6 & 36 \\
\hline Mus atratus .......... & 111862 & $\ldots .$. do ... & 316 & 150 & 166 & 38 & 35.6 \\
\hline Do............ & 111863 & Male .. & 356 & 175 & 181 & 38 & 35 \\
\hline 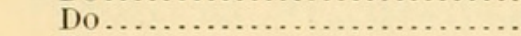 & 111864 & Female & 352 & 170 & 182 & 40 & 38 \\
\hline 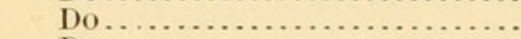 & 111865 & Male .. & & 195 & & 39 & 37 \\
\hline Do........... & 111866 & Female.. & 352 & 172 & 180 & 39 & 36 \\
\hline Do............. & 111867 & Male .... & 322 & 149 & 17 & 39 & 36 \\
\hline Do......... & 1111868 & Female... & 342 & 160 & 182 & 47 & 44.6 \\
\hline Do............ & 111869 & Male.... . & 372 & 182 & 190 & 39 & 36.6 \\
\hline Mus burrus ........ & 111803 & Female.. & 405 & 195 & 210 & 42 & 40 \\
\hline Do $\ldots \ldots \ldots \ldots$ & 111804 & Male .... & 410 & 207 & 203 & 43 & 41 \\
\hline Do $\ldots \ldots \ldots \ldots$. & 111805 & ...... do . & 435 & 225 & 210 & 43 & 41 \\
\hline Do $\ldots \ldots \ldots \ldots$. & 111806 & Female.. & 382 & 191 & 191 & 41 & 39 \\
\hline …........ & 111807 & Male ... & 398 & 196 & 202 & 42.6 & 41 \\
\hline Do..... & 111808 & Female. & 402 & 200 & 202 & 42 & 40 \\
\hline Do..... & 111809 & Male .... & 404 & 206 & 198 & 43 & 41.4 \\
\hline Do............ & 111810 & ..... do ... & 385 & 197 & 188 & 43 & 41 \\
\hline 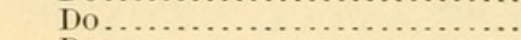 & ${ }^{1} 111811$ & Female... & 430 & 215 & 215 & 43 & 41.4 \\
\hline 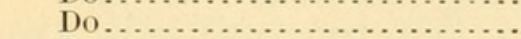 & 111812 & ..... do .... & 388 & 195 & 193 & 41 & 39 \\
\hline Do........... & 111813 & ..... do... & 345 & 165 & 180 & 42 & 40 \\
\hline Do.......... & 111814 & ..... do. & 416 & 216 & 200 & 42 & 40 \\
\hline
\end{tabular}

1 Type.

MUS ALEXANDRINUS E. Geoffroy.

A specimen of the roof rat was taken by Dr. Abbott on Nanhauri Island, Nicobars, February 10, 1901. The measurements are as follows: Total length, $357 \mathrm{~mm}$; head and body, 172; tail, 185; hind foot, 35 (33). This is the first positive record of the species from the Nicobars or Andamans.

\section{Genus PARADOXURUS F. Cuvier.}

\section{PARADOXURUS TYTLERII Tytler.}

1860. Paradoxurus musanga vel typus (?) Blyth, Journ. Asiat. Soc. Bengal, XXIX, p. 102. (Port Blair.)

1864. Paradoxurus tytlerii Tyther, Journ. Asiat. Soc. Bengal, XXXIII, p. 188. (Andaman Islands.)

The Andaman palmeivet was first recorded by Blyth in 1860 on the basis of an imperfect skeleton sent to the museum of the Asiatic Society by Captain Hodge, then in command of the guard ship Sesostris at Port Blair. The specimen was in too imperfect condition to be satisfactorily identified with any of the known members of the genus. Four years later Lieutenant-Colonel Tytler, governor of Port Blair, communicated to the Asiatic Society a description of a new species of Paradoxurus from the Andaman Islands, by way of introduction to which he remarks:

As the mammalia found on these islands must be of interest, I beg to send you the following description of a NEw Paradoxurus which I have named after myself. 
Without doubt this animal is the same as that previously mentioned by Blyth. Apparently Blanford is the only other author who has dealt with the animal. He refers it to Paradoxums grayi, with the observation that it is smaller than the continental form. ${ }^{1}$

Dr. Abbott secured one specimen, a fully adult male with somewhat worn teeth. It was trapped in the forest on the shore of MacPherson Strait, South Andaman Island, January 17, 1901. Many tracks were seen in the sand of the neighboring beach. The measurements of this individual are as follows: Total length, 1,040 mm.; head and body, 550 ; tail, 490; hind foot (without claws), 83; ear from meatus, 42; ear from crown, 31; width of ear, 30. Skull: Greatest length, 108; basal length, 103; basilar length, 100; occipito-nasal length (median), 95; length of nasals (median), 23; length of bony palate (median), 53; width of palate between anterior premolars, 14; width between posterior molars, 29; zygomatic breadth, 61 ; least interobital breadth, 21 ; distance between anterior extremities of audital bullæ, 16.6 ; width of braincase above roots of zygomata, 33.6 ; mandible, 82 ; maxillary toothrow (exclusive of incisors), 39; mandibular toothrow (exclusive of incisors), 44 .

\section{Genus FELIS Linnæus.}

\section{FELIS CHAUS Gueldenstædt.}

1863. Felis chaus Blyth, Appendix to Mouat's Adventures and Researches among the Andaman Islanders, p. 351.

That a small yellowish brown cat occurs on South Andaman Island seems fairly well established by the note of Colonel Tytler, quoted by Blyth in the appendix to Mouat's Adventures and Researches. No specimen of the animal has ever been examined, as Tytler merely saw a living individual at a distance of some 150 yards, and the skull found by Dr. Mouat on the occasion of his visit to the island was subsequently lost. Blyth suggests that the animal is probably Felis chaus, but this is purely a matter of conjecture.

\section{Genus TUPAIA Raffles.}

\section{TUPAIA NICOBARICA NICOBARICA (Zelebor).}

1861. Cladobates nicobaricus Fitzinger, Sitzungsber. math.-naturwissensch. Cl.

Kais. Akad. Wissensch., Wien, XLII (1860), p. 392 (nomen nudum).

1869. Cladobates nicobaricus Zelebor, Reise der österreich. Fregatte Novara, Zool., I (Wirbelthiere), 1, Mamm., p. 17. (Great Nicobar.)

1879. Tupaia nicobarica Anderson, Anat. and Zool. Researches, Western Yunnan (1878), p. 136.

Unless the "large squirrel" observed by Capt. Harold Lewis in $1846^{2}$ may have been this species, the Nicobar treeshrew escaped notice

${ }^{1}$ Proc. Zool. Soc. London, 1885, p. 805. The Fauna of British India, I, Mamm., p. $113,1888$.

${ }^{2}$ Journ Asiat. Soc. Bengal, XV, p. 367. 
until the year 1858, when it was discovered by the naturalists of the Novara expedition. They found it on all the larger Nicobar islands, but most abundantly on Great Nicobar. According to their account it is a noisy animal, uttering a long-drawn "dänh-dänh" when disturbed or pursued. Nothing of importance has been added to this very meager account of the animal's habit. Dr. Abbott describes it as very active, and generally found in the treetops; apparently more strictly arboreal than other members of the genus.

The series of 18 skins obtained by Dr. Abbott shows that the species is rather variable in color, somewhat more so, in fact, than other members of the genus. In most specimens the color-pattern is like that shown in Zelebor's plate - that is, the dark dorsal area is continued forward along side of shoulder to join that of head, thus completely isolating the yellowish brown mantle from the pale area of the underparts. In others the dark area invades the mantle, reducing it occasionally to a mere tace, but never to its entire obliteration. On the other hand, in a few skins the mantle is so extended as to cover the entire head and shoulders, thus excluding the dark area from the region in front of a point halfway between shoulder and hip. The color of the tail varies from nearly black and concolor with the dark dorsal area to a yellowish brown like that of belly. Though there is a difference in appearance between the brown of the mantle and that of the belly, it is chiefly if not wholly due to the dense silky quality of the fur of the upper parts as compared with the loose, lusterless texture of that beneath. The actual color is difficult to describe, as nothing like it can be found in Ridgway's nomenclature. It most closely approaches buff (Pl. v, fig. 13), but is strongly tinged with wood brown, the glossy fur of the mantle often imparting a peculiar vividness without actually changing the shade. On thighs there is added a faint tinge of drab, which in some specimens appears also on mantle and underparts.

TUPAIA NICOBARICA SURDA, new subspecies.

Type.-Adult male (skin and skull), No. 111757, U.S.N.M. Collected on Little Nicobar Island, March 1, 1901, by Dr. W. L. Abbott. Original number, 899 .

Characters. - Similar to Tupaia nicobarica nicobarica, but light areas of pelage much less yellow and less contrasted with dark areas.

Color.-Type: Entire underparts, front and hind legs, head, neck, shoulders, and anterior half of back wood brown, tinged with drab posteriorly and on upper parts, with buff elsewhere. An indefinite dark shade on forehead and another on nape, the latter sending back a faint median streak and two still more indistinct lateral shades. On underparts and inner surface of legs the hairs are dull and lusterless and the color clear, but on upper parts and outer surface of legs the 
glossy texture of the hairs, together with a very fine annulation (particularly in mantle), imparts a faintly grizzled aspect. Posterior half of back very dark brown, almost black, with here and there a hair which shows a trace of wood brown annulation. Tail deep burnt umber throughout, except at extreme base, where it shades abruptly to black above and to the drab wood brown of belly below.

In other specimens the dark dorsal area is lightened to prouts brown (of a shade considerably darker than Ridgway's Pl. III, fig. 11) and the tail to a pale burnt umber glossed with russet. In most cases, however, the color is like that of the type, or nearly so.

Skull and teeth.-I can not find that the skull and teeth differ from those of Tupaia nicobarica nicobarica.

Measurements. - External measurements of type: Total length, 410 mm.; head and body, 190; tail vertebræ, 220; hind foot, 48 (45); ear from meatus, 16; ear from crown, 7; width of ear, 13.4. Average of ten specimens from the type locality: Total length, 388 (370-410); head and body, 176 (170-190); tail, 212 (200-220); hind foot, 47.5 $(47-49)$; hind foot without claws, 44.4 (43.4-45). For detailed external measurements see table, page 776 .

Cranial measurements of type: Greatest length, $54(53)^{1} \mathrm{~mm}$; basal length, 47 (46); basilar length, 46 (45); median palatal length, 28 (27.6); length of nasals (about), 18 (18); distance from lachrymal notch to tip of premaxillary, $21.8(20.8)$; diastema, $5(4.6)$; width of palate between anterior molars, 9.6 (9.8); lachrymal breadth, 18.4 (17.8); breadth of rostrum at middle of diastema, 7 (7.4); least interorbital breadth, 17.4 (16.4); zygomatic breadth, 28 (28.6); least distance from inion to rim of orbit, 26 (26.6); occipital depth, 12.4 (12); depth from middle of parietal to lower surface of audital bulla, 18 (17.4); depth of rostrum at base of nasals, $8(8)$; depth of rostrum at middle of diastema, 5.8 (5.4); mandible, 37 (36); maxillary toothrow (behind diastema, 19 (19); mandibular toothrow (behind diastema) 17 (17).

Specimens examined.-Seventeen, all from Little Nicobar Island.

Remarks.-Typical individuals representing the majority of specimens are instantly recognizable, as compared with similar material from Great Nicobar, by the dull, relatively lusterless, and ill-contrasted color of the mantle and thighs, as well as by the less yellow underparts. The mantle is less often outlined by a dark shade at the side than in the typical form. Occasionally a specimen may be found which can not be certainly referred to either race, but taking the series as a whole the characters are readily appreciable.

\footnotetext{
${ }^{1}$ Measurements in parentheses are those of an adult male Tupaia nicobarica nicobarica.
} 
Table of measurements of Tupaia nicobarica nicobarica and T. niobarica surda.

\begin{tabular}{|c|c|c|c|c|c|c|c|}
\hline Name. & Number. & Sex. & $\begin{array}{c}\text { Total } \\
\text { length. }\end{array}$ & $\begin{array}{l}\text { Head } \\
\text { and } \\
\text { body. }\end{array}$ & Tail. & $\begin{array}{l}\text { Hind } \\
\text { foot. }\end{array}$ & $\begin{array}{l}\text { Hind foot } \\
\text { without } \\
\text { claws. }\end{array}$ \\
\hline Tupaia nicobarica nicobarica .. & 111764 & Female ad.. & $\begin{array}{l}\mathrm{Mm}_{385} \\
.\end{array}$ & ${ }_{175}$. & $\underset{210}{M m}$. & ${ }_{47.6}$ & $\mathrm{Mm}_{44}$ \\
\hline Do.... & 111765 & .....do...... & 410 & 190 & 220 & 49.6 & $\begin{array}{l}44 \\
46\end{array}$ \\
\hline Do............. & 111771 & .....do... & 410 & 187 & 223 & 50 & 47 \\
\hline Do... & 111773 & ..... do. . & 392 & 187 & 205 & 50 & 46 \\
\hline Do......... & 111777 & ..... do . & 413 & 192 & 221 & 48 & 45 \\
\hline Do.......... & 111778 & ..... do . & 395 & 180 & 215 & 47.4 & 44 \\
\hline Do... & 111779 & $\ldots \ldots$ do .... & 402 & 187 & 215 & 48 & 45 \\
\hline Do... & 111766 & Male juv & 383 & 180 & 203 & 46 & 44 \\
\hline Do... & 111767 & Male ad .. & 415 & 195 & 220 & 49.6 & 46 \\
\hline Do... & 111768 & ..... do .... & 375 & 185 & 190 & 50 & 46 \\
\hline n......... & 111769 & ..... do.... & 380 & 180 & 200 & 47 & 44 \\
\hline …… & 111770 & ..... do. & 390 & 180 & 210 & 47 & 44 \\
\hline $\ldots \ldots \ldots \cdots \cdots$ & 111772 & ..... do . & 396 & 190 & 206 & 47 & 44 \\
\hline Do............. & 111774 & ..... do. & 410 & 195 & 215 & 48 & 45 \\
\hline Do............. & 111776 & ...... do . & 410 & 178 & 232 & 48 & 45 \\
\hline Do. $\ldots \ldots \ldots \ldots \ldots \ldots \ldots$ & 111780 & $\ldots \ldots$ do & 416 & 191 & 225 & 47 & 44.6 \\
\hline Tupaia nicobarica surda ...... & 111749 & Male ... & 404 & 189 & 215 & 47 & 43.4 \\
\hline Do...................... & 111750 & $\ldots .$. do .... & 390 & 170 & 220 & 49 & 45.6 \\
\hline Do.. & 111751 & Female..... & 390 & 170 & 220 & 47 & 44 \\
\hline Do.. & 111752 & Male .... & 390 & 190 & 200 & 49 & 45 \\
\hline 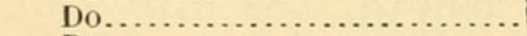 & 111753 & $\ldots .$. do $\ldots . .$. & 380 & 180 & 200 & 47 & \\
\hline Do.......................... & 111754 & Female..... & 405 & 190 & 215 & 47 & 44 \\
\hline 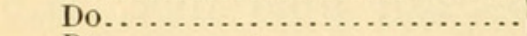 & 111755 & $\ldots \ldots$ do ... & 395 & 185 & 210 & 47 & \\
\hline Do $\ldots \ldots \ldots, \ldots \ldots, \ldots$ & 111756 & Male ... & 390 & 175 & 215 & 47 & 44.6 \\
\hline Do $\ldots \ldots \ldots \ldots \ldots \ldots$ & ${ }^{1} 111757$ & ..... do ... & 410 & 190 & 220 & & 45 \\
\hline 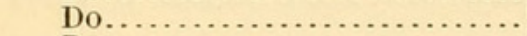 & 111758 & Female.. & 390 & 180 & 210 & 47.6 & 44.6 \\
\hline 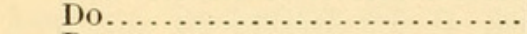 & 111759 & Male ..... & 400 & 185 & 215 & 47. & 44 \\
\hline Do & 111760 & ..... do .... & 403 & 178 & 225 & 47.6 & 45 \\
\hline 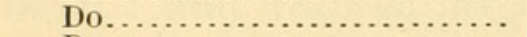 & 111761 & ...... do ... & 400 & 180 & 220 & 48 & 45 \\
\hline 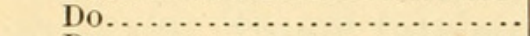 & 111762 & Female... & 400 & 190 & 210 & 49 & 45.6 \\
\hline 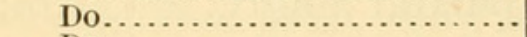 & 111763 & ..... do .... & 382 & 182 & 200 & 48 & 45 \\
\hline Do........................... & 111775 & ..... do ... & 410 & 185 & 225 & 48.4 & 45 \\
\hline Do.......................... & 111781 & ..... do... & 420 & 190 & 230 & & \\
\hline
\end{tabular}

1 Type.

\section{GENUS CROCIDURA Wagler.}

CROCIDURA NICOBARICA, new species.

Type.-Adult female (in alcohol), No. 111788, U.S.N.M. Collected on Great Nicobar Island, March 15, 1901, by Dr. W. L. Abbott. Original number, 931.

Characters.-Largest known oriental member of the subgenus Crocidura; total length, about $210 \mathrm{~mm}$. General color, sooty brown.

Fur.-The fur is dense and velvety, the hairs on middle of back about $4 \mathrm{~mm}$. in length, with a few longer ones interspersed.

Color.-Dorsal surface prouts brown (slightly darker than Ridgway's Pl. III, fig. 11), somewhat grizzled in certain lights by the silvery gray reflections from the hairs. Sides, underparts, and both surfaces of legs broccoli brown, slightly washed with wood brown. On middle of chest there is an elongate patch of gray, very nearly Ridgway's gray No. 8, but faintly washed with broccoli brown. Ears, tail, and feet an indefinite fleshy brownish, the thin sprinkling of minute hairs not affecting the color.

Tail. - The tail is so minutely and indistinctly annulated that, at first sight, its surface appears to be smooth. On close inspection the rings become visible, about thirty to the centimeter at middle. Numerous dark hairs with silvery reflections spring from the border of each 
ring. In length they slightly exceed the width of the rings. These hairs are invisible without the aid of a lens, except when seen in profile against a white surface, or when certain lights cause them to appear as a silvery pubescent sheen. With the short hairs are sparsely intermingled cilia, $10 \mathrm{~mm}$. in length.

Mamme.-Apparently there are two inguinal mammæ on each side, but the specimen is sufficiently mutilated to make the count uncertain.

Feet.-Both soles and palms are naked and 6 -tuberculate. The surface between the tubercles is finely reticulated.

Skull. - The skull exactly resembles that of Kashmir specimens of Crocidura (Pachyura) "murina," except that the size is a trifle less. So far as can be determined from a single specimen the skull of the fully developed adult Nicobar shrew is less angular than that of $C$. "murina" of the same age.

Teeth. - The teeth resemble those of Crocidura "murina." The first unicuspid is, however, distinctly smaller than in the Kashmir animal, and the two succeeding teeth are faintly larger. As a result there is less contrast in the size of the unicuspids, though the relative proportions remain the same - that is, the first is much larger than the third, which in turn exceeds the second. Of the fourth unicuspid, well developed in $C$. " murina," there is no trace.

Measurements. -External measurements of type: Total length, 210 mm.; head and body, 120 ; tail, $90 ;^{1}$ hind foot, $24^{1}$ (23); ear from meatus, 11; ear from crown, 5; width of ear, 11.

Cranial measurements of type: Greatest length (exclusive of incisors), 27 (29) mm.; ${ }^{2}$ basal length, 26 (28); basilar length, 24 (26); palatal length, 11.8 (12.4); width of palate between middle molars, 3.6 (4); mastoid breadth, 11.6 (12.8); lachrymal breadth, 6.2 (6.2); mandible (without incisor), 15 (14.8); maxillary toothrow, 12.8 (13); mandibular toothrow, 12 (12).

Specimens examined.-One, the type.

Remarks. - This species is readily distinguishable among the hitherto known oriental members of the subgenus Crocidura by its very large size, a character in which it is approached by its representative in the Andaman Islands only. Some of the larger African species are, however, of about the same measurements.

CROCIDURA ANDAMANENSIS, new species.

Type.-Adult male (skin and skull), No. 111825, U.S.N.M. Collected at MacPherson Strait, South Andaman I-land, January 16, 1901, by Dr. W. L. Abbott. Original number, 851.

\footnotetext{
${ }^{1}$ Slightly damaged.

'Measurements in parentheses are those of a female Crocidura "murina," from Kashmir. It is from an individual which appears to be full grown, but in which the suture between the basioccipital and basiphenoid is still open. In the type of C. nicobarica this suture is obliterated.
} 
Characters.-In size nearly equal to Crocidura nicobarica; general color, bluish gray.

Fur.-The fur is somewhat longer and less dense than in the type of $C$. nicobarica, that on middle of back about $8 \mathrm{~mm}$. in length. This character is probably individual.

Color.-Entire body and head gray (very nearly Ridgway's No. 8), everywhere washed with broccoli brown. This wash is most noticeable on dorsal surface, where the effect of the two colors is drab gray. On underparts the brown is distinctly visible in some lights, scarcely so in others. Feet, yellowish brown; tail and ears, dark brown.

Skull.-The skull is in every way similar to that of Crocidura nicobarica, except that it is somewhat smaller.

Teeth.-In general the teeth of Crocidura andamanensis closely resemble those of $C$. nicobarica. The unicuspids are, however, actually as well as relatively larger, and the contrast in size between the second and the other two is more marked.

Measurements. - External measurements of type: Total length, 200 mm.; head and body, 114; tail, 86; hind foot, 26 (25).

Cranial measurements of type: Greatest length (exclusive of incisors), $25.6 \mathrm{~mm}$; basal length, 24.8 ; basilar length, 22; palatal length, 11 ; width of palate between middle molars, 3.2 ; mastoid breadth, 11; lachrymal breadth, 6 ; mandible (without incisor), 15 ; maxillary toothrow, 12; mandibular toothrow, 11.

Specimens examined.-One, the type.

Remarks. - This species, though closely related to Crocidura nicobarica, appears to be well characterized by its smaller size, larger unicuspid teeth, and distinctly gray color.

\section{Genus SCOTOPHILUS Leach.}

\section{SCOTOPHILUS TEMMINCKII (Horsfield).}

1863. Nycticejus temminckii BLyth, Appendix to Mouat's Adventures and Researches among the Andaman Islanders, p. 354 (Nicobars).

In the Appendix to Monat's Apventures and Researches Blyth writes: "From the Nicobar's have been received Hipposideros murinus (Elliot) and Nycticejus temminckii (Horsfield) . . ." This is the only record of Temminck's bat from either group of islands. It was apparently overlooked by Blanford, who does not include either Nicobars or Andamans in the range of the species.

Genus TYLONYCTERIS Peters.

TYLONYCTERIS PACHYPUS (Temminck).

1876. Vesperugo pachypus Dobson, Monogr. Asiat. Chiropt., p. 210 (Andamans).

Although they are not mentioned in the body of the work, Dobson records sixteen Andaman specimens of this bat in the catalogue of Chiroptera in the Indian Museum forming part of the Appendix to the 
Monograph of Asiatic Chiroptera. Nothing is known of the history of these specimens except that they were collected in 1871 and 1872 by Dr. Stoliczka, J. Homfray, and James Wood-Mason.

\section{Genus PIPISTRELLUS Kaup.}

\section{PIPISTRELLUS TICKELLI (Blyth).}

1876. Vesperugo tickelli DoBson, Monogr. Asiat. Chiropt., p. 208 (Andamans).

Three specimens of Tickell's bat, collected by Colonel Tytler in the Andaman Islands, are recorded by Dobson in the catalogue of specimens of Chiroptera in the Indian Museum, which forms part of the Appendix to the Monograph of the Asiatic Chiroptera. Nothing further is known of the animal as an inhabitant of the islands.

\section{PIPISTRELLUS CAMORT $Æ$, new species.}

1861. ?Vesperugo nicobaricus Fitzinger, Sitzungsber. Math.-Naturwissensch. Cl. Kais. Akad. Wissensch., Wien, XLII (1860), p. 390 (nomen nudum).

1869. ? Vesperugo tenuis Zelebor, Reise der österreichischen Fregatte Novara, Zool., I (Wirbelthiere), 1, Mamm., p. 16 (Nicobars).

1876. ? Vesperugo abramus Dobson, Monogr. Asiat. Chiropt., p. 212 (Nicobars).

Type.-Adult male (in alcohol) No. 111897, U.S.N.M. Collected on Kamorta Island, Nicobar Islands, February 12, 1901, by Dr. W. L. Abbott.

Characters. - Externally much like Javan specimens of Pipistrellus abramus, but slightly smaller, the ears shorter and broader, and penis considerably shorter than tibia. Skull with broader rostrum and smaller audital bullæ. Teeth as in P.abramus, the inner upper incisor bifid.

Ears.-The ear is moderately long; laid forward it extends about to nostril. Anterior border nearly straight from base to broadly roundedoff tip. Posterior border straight from just below tip to about middle, then strongly convex to noteh isolating low but well-developed antitragus. Tragus short and broad, its greatest width nearly equal to length of anterior border. Posterior outline evenly convex except where interrupted by a small but very distinct lobe near base. Anterior border slightly concave.

Feet.-The foot is smaller than in Pipistrellus abramis. Calcar fading insensibly into uropatagium, but provided with a very distinct keel, considerably larger than that of $P$. abramus.

Membranes. - The membranes are thin and delicate, but do not show any peculiarities of importance. They are naked except close to body. Wing from base of outer toe.

Penis.--The penis, though much larger than in Pipistrellus pipistrellus and $P$. kuhli, lacks the enormous development characteristic of $P$. abramus. Its length equals about two-thirds that of tibia.

Color.-After several months immersion in alcohol the color is a 
uniform dark brown above (the exact shade intermediate between the bistre and burnt umber of Ridgway), and a lighter brown (between wood brown and cinnamon) beneath. Fur everywhere blackish at base. Ears and membranes blackish brown, the wing faintly edged with white.

Skull and teeth. - The skull resembles that of Pipistrellus abramus in general size and form, but the rostral portion is very noticeably broader and shorter. Audital bullæ smaller than in $P$. abramus, but not different in form.

Teeth as in Pipistrellus abramus, but more robust.

Measurements.-External measurements of type: Total length, 78 mm. (80); ${ }^{1}$ head and body, 48 (48); tail, 30 (32); tibia, 12 (11.6); foot, 6.8 (6.6); penis, 9; forearm, 31.6 (32); thumb, 5 (5.4); second digit, 31 (30); third digit, 52 (55); fourth digit, 47 (51); fifth digit, 40 (42); ear from meatus, 11.4 (12); ear from crown, 9 (9); width of ear, 10.6 (10.6); tragus (anterior border), 3 (4).

Cranial measurements of type: Greatest length, $12.6 \mathrm{~mm}$. (13); ${ }^{2}$ basal length, 12 (12.2); basilar length, 9 (9.8); zygomatic breadth, 9 (8.8); least interorbital breadth, 3.6 (3.6); greatest length of braincase, $7.8(8)$; greatest breadth of braincase above roots of zygomata, 7 (6.8); mandible, 10 (9.8); maxillary toothrow (exclusive of incisors), 5 (5); mandibular toothrow (exclusive of incisors), 5 (5).

Specimens examined.-Two (in alcohol), both from the type locality.

Remarks. - Pipistrellus camortce appears to be a well-marked species related more closely to $P$. abramus than to any other. It is undoubtedly the bat which Dobson recorded from the Nicobars in the list of specimens of Vesperugo abramus in the collection of the East Indian Museum. Probably it is also the species named Vesperugo nicobaricus by Fitzinger, but afterwards regarded by Zelebor as $V$. tenuis.

\section{Genus MINIOPTERUS Bonaparte.}

\section{MINIOPTERUS PUSILLUS Dobson.}

1876. [Miniopterus schreibersi] var. $\alpha$ Miniopterus pusillus Dobson, Monogr. Asiat. Chiropt., p. 162 (Nicobar Islands).

Although the range of this bat is given by Dobson as probably including the same countries as that of M. schreibersii, Anderson states that the type specimen in the Indian Museum, Calcutta, was collected among the Nicobar Islands by Dr. Stoliczka. ${ }^{3}$ Nothing is known of the species beyond the facts that it is apparently common on the Nicobar Islands, and that it has been recorded from the Andamans and also from Madras. Dr. Abbott did not meet with it.

${ }^{1}$ Measurements in parenthesis are those of an adult female from the type locality.

${ }^{2}$ Measurements in parenthesis are those of an adult female Pipistrellus abramus from Buitenzorg, Java.

${ }^{3}$ Catal. Mamm. Ind. Mus. Calcutta, 1881, p. 146. Though no definite locality is given for the type specimen, filteen others are recorded from Kachal Island. 


\section{Genus RHINOLOPHUS E. Geoffroy.}

\section{RHINOLOPHUS ANDAMANENSIS Dobson.}

1872. Rhinolophus andamanensis DoBson, Journ. Asiat. Soc. Bengal, XLI, Pt. 2, p. 337. (South Andaman Island.)

The type and only known specimen of this bat was collected by $\mathrm{Mr}$. Homfray, assistant superintendent at Port Blair. Nothing is known of the animal's habits or distribution.

\section{Genus HIPPOSIDEROS Leach.}

\section{HIPPOSIDEROS NICOBARENSIS (Blanford).}

1871. Phyllorhina nicobarensis DoBson, Journ. Asiat. Soc. Bengal, XL, Pt. 2, p. 262.

1891. Hipposideros nicobarensis Blanford, The Fauna of British India, Mamm., p. 286.

Nothing is known of this bat, except that the type specimen, now in the collection of the Indian Museum, Calcutta, was collected among the Nicobar Islands by Dr. Stoliczka. According to Dobson its relationships are with $H$. diedemata.

\section{HIPPOSIDEROS NICOBARULÆ, new species.}

1876. Phyllorhina bicolor Dobson, Monogr. Asiat. Chiropt., p. 70 (Nicobars).

Type.-Adult male (in alcohol), No. 111874, U.S.N.M. Collected on Little Nicobar Island, March 2, 1901, by Dr. W. L. Abbott.

Characters.-Closely related to Hipposideros bicolor and $H$. fulvus, with which it agrees in all general external features. Size much less than that of $H$. fulva and slightly greater than in $H$. bicolor. Terminal erect portion of noseleaf broader than in $H$. bicolor; skull more inflated in front of orbits, and with broader palate and interpterygoid region.

Noseleaf.-The noseleaf is slightly larger than that of Hipposideros bicolor, but not essentially different in form. The posterior erect portion is slightly broader, but the difference may be in part sexual, as the only specimen of $\Pi$. bicolor at hand is a female.

Color. - Two distinct color phases occur. In the dark phase, represented by the type, the hairs of the back are seal brown through terminal third, light smoke gray basally in strong contrast. On underparts the fur is broccoli brown throughout, the hairs slightly darker at tip. In the light phase the whole body is mars brown, the hairs everywhere light gray at base, but this feature most noticeable on back. Ears and membranes blackish. This description is based on specimens that have been immersed in alcohol for about six months.

Skull and teeth. - The skull is so much smaller than that of Hipposideros fulvus that it needs no special comparison. From the skull of H. bicolor it differs in slightly larger size and in several details of structure. The width of the constricted portion of the palate is con- 
siderably greater than in the allied species, and the interpterygoid space is wider in proportion to its length. Antorbital region more inflated than in either of the allied species.

The teeth show no peculiarities of form. They are intermediate in size between those of Hipposideros bicolor and II. fulvus.

Measurements.-For external measurements see table below.

Cranial measurements of type: Greatest length, 16.4 (16) mm.; ${ }^{1}$ basal length, 14 (14); basilar length, 12.8 (12.8); zygomatic breadth, $8.4(8.2)$; least interorbital breadth, $2.2(2.4)$; mastoid breadth, 9.4 (8.6); greatest length of braincase, $10(10)$; greatest breadth of braincase above roots of zygomata, 7 (7); frontopalatal depth (at middle of molar series), 3 (3); depth of braincase, 5.8 (5.4); maxillary toothrow (exclusive of incisors), 5.6 (5.4); mandible, 10 (10); mandibular toothrow (exclusive of incisors), 6 (6).

Specimens examined. - Twenty-five, all from the type locality.

Remarks.-Though in some respects intermediate between Hipposideros bicolor and $H$. fulvus, this species is so readily distinguishable as to need no special comparison.

Table of measurements of Hipposideros nicobarulx.

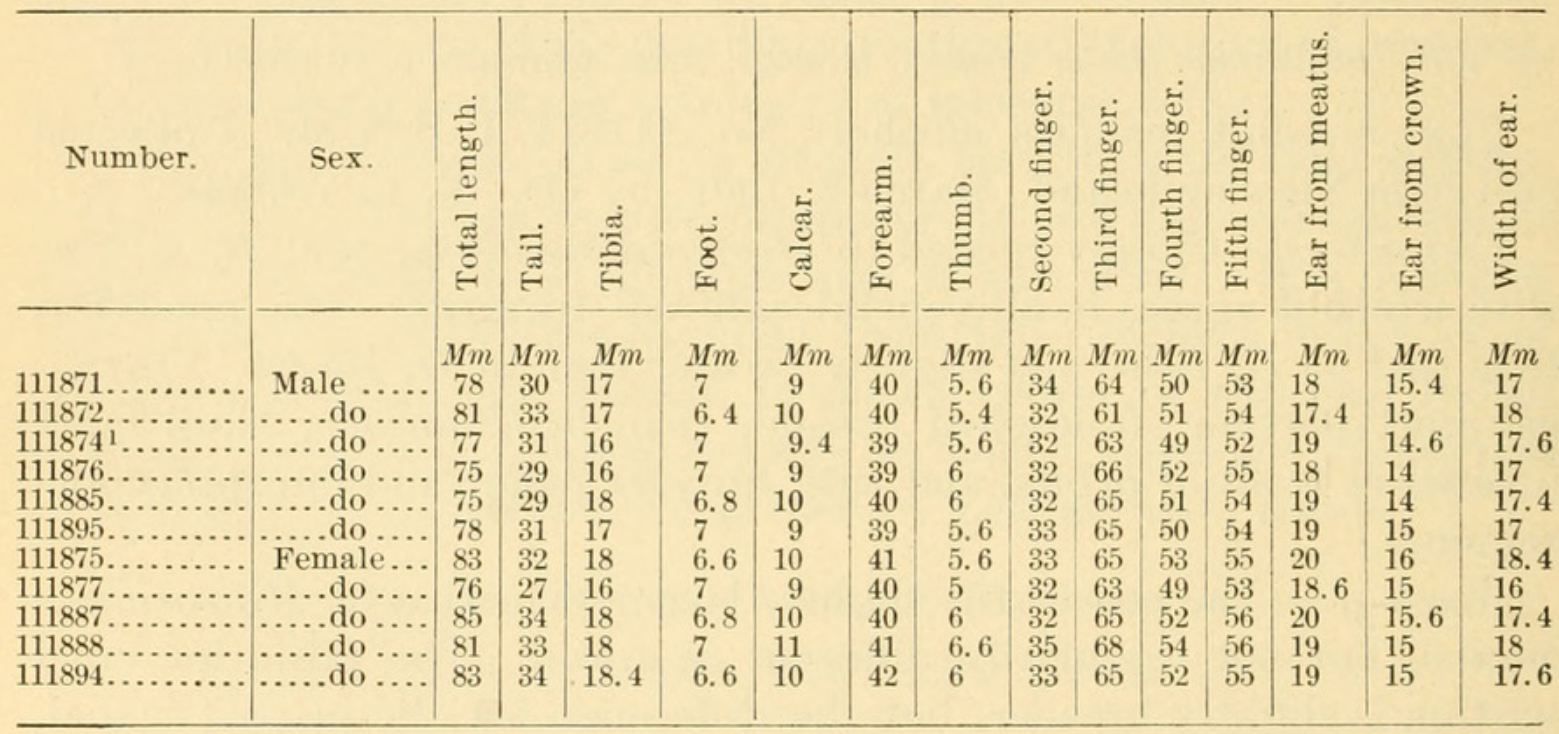

1 Type.

\section{Genus PTEROPUS Brisson.}

\section{PTEROPUS NICOBARICUS Zelebor.}

1846. Pteropus edulis Blyth, Journ. Asiat. Soc. Bengal, XV, p. 367. (Nicobar Islands.)

1861. Pteropus nicobaricus Fitzinger, Sitzungsber. Math.-Naturwissensch. Cl. Kais. Akad. Wissensch., Wien, XLII (1860), p. 389. 1861. (Nomen nudum.) 1869. Pteropus nicobaricus Zelebor, Reise der osterreichischen Frigatte Novara, Zool., I (Wirbelthiere), 1, Mamm., p. 11. (Car. Nicobar.)

The earliest notice of the Nicobar fruitbat appears to be that in

${ }^{1}$ Measurements in parentheses are those of an adult female Hipposideros bicolor from Sumatra. Some of the cranial dimensions of an adult male $H$. fulvus from Deccan, India, are as follows: Greatest length, 18; basal length, 15.6; zygomatic breadth, 9.4; interorbital constriction, 2.8; maxillary toothrow (exclusive of incisors), 6.4. 
Blyth's Notes on the Fauna of the Nicobar Islands, published in 1846. ${ }^{1}$ The animal was here recorded as Pteropus edulis; but that Blyth was not satisfied with this determination is shown by the stress laid on the peculiarities of the specimens. His entire account is as follows:

Pteropus edulis: Pt. javanicus, Horsf,, etc. Three specimens are remarkable for having the throat and front of the neck black, the head blackish, the nape dull reddish-brown, the back shining black, flanks and vent dull black, and the rest of the underparts dull reddish brown, much paler in the center.

This is an excellent description of Pteropus nicobaricus. In 1863 Blyth applied to these specimens the name Pteropus melanotus, but this, according to Dobson, at least ${ }^{2}$ - I have not seen the work where it occurs ${ }^{3}$ - is a nomen nudum. Meanwhile the naturalists of the Novara expedition had discovered the animal on Car Nicobar; and the name Pteropus nicobaricus had been published. This name as it appeared in 1860 was purely a nomen nudum, and not until 1869 was it properly defined. The correct specific name for this bat is therefore open to serious question, since any positive means of connecting Blyth's Pteropus melanotus of 1863 with his description of 1846 would preclude the use of nicobaricus.

In the supplement to Mouat's Adventures and Researches Among the Andaman Islanders, 1863, Blyth states that no Pteropus has yet been observed upon the Andamans; but in 1876 Dobson records $P$. nicobaricus from both Andamans and Nicobars, while two years later he gives the range as including the Andamans, Nicobars, Java, and Pulo Condor. I am inclined to doubt the authenticity of these records, though I have had no opportunity of examining the specimens on which they are based. That a Pteropus is abundant on some of the Andaman Islands is shown by Hume's account of a species observed in 1873.

As we were returning [he writes],${ }^{4}$ thousands of huge flying foxes (Pleropus nicobaricus they proved to be) poured out from the higher trees on this side of the island [the smaller Jolly Boy] in one continuous stream. We shot five or six; those that were not quite dead we retrieved as they floated, but those that were killed outright sank like stones, and we only succeeded in fishing up one of these that we marked exactly, and then saw lying black on the coral bottom that shone up white and bright in the moonlight.

Other records of specimens from the Andamans may be found in Anderson's Catalogue of the Mammalia in the Indian Museum. ${ }^{5}$ Here is mentioned also a skull from Mergui, but it has no history, and the locality given is probably erroneous. ${ }^{6}$

\footnotetext{
${ }^{1}$ Journ. Asiat. Soc. Bengal, XV, pp. 367-379 (Mammalia, pp. 367-368).

${ }^{2}$ Monogr. Asiat. Chiropt., 1876, p. 17.

${ }^{3}$ Catal. Mamm. Mus. Asiat. Soc. Bengal, 1863, p. 20.

${ }^{4}$ Stray Feathers, II, p. 61,1874 .

${ }^{5}$ Pp. 102-103.

${ }^{6}$ See Blanford, The Fauna of British India, Mamm., 1891, p. 261.
} 
Dr. Abbott obtained sixteen adults, eight from Great Nicobar, and eight from Tillanchong. On Car Nicobar, the type locality of the species, he found only the very different $P$. faumulus.

There is considerable individual variation in both color and size, but taken as a whole the series from the two islands are not distinguishable from each other. The variation in size is shown in the table of measurements below; that in color is for the most part confined to the mantle. The entire head in front of ears and the back is blackish, only occasionally tinged with brown. Underparts blackish along sides and across throat, the lower neck usually suffused with an indefinite reddish brown. Middle of chest and belly light brown, in strong contrast with sides and throat. The color of this area is essentially the same as that of the mantle, and like the latter very difficult to describe with any degree of accuracy. In none of the specimens, however, is it as pale as the extreme phase of the mantle. In a general way it may be described as an ochraceous buff, rather yellower than that of Ridgway (Pl. v, No. 10). Along median line of belly this is usually tinged with drab, and at sides, just before merging into the black lateral area, with russet. The hairs have a conspicuous silky gloss in certain lights. The mantle, while generally of the same ground color is occasionally a very light buff or cream buff. In these specimens the color is nearly uniform, but in the more usual phase the median and anterior portion of the mantle is strongly suffused with red. This suffusion may be a dull brownish hazel, a clear cinnamon rufous, or both on different parts of the mantle. In such cases the browner tints are usually near center. Ears, membranes, feet, and naked portion of face uniform blackish brown in the dried specimens.

Table of measurements of Pteropus nicobaricus.

\begin{tabular}{|c|c|c|c|c|c|c|c|c|c|c|c|c|c|c|c|c|}
\hline Locality. & $\begin{array}{l}\text { Num- } \\
\text { ber. }\end{array}$ & Sex. & 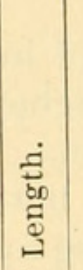 & 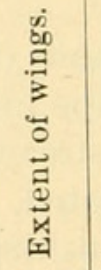 & 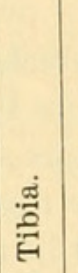 & $\begin{array}{l}\stackrel{8}{\circ} \\
\text { \& }\end{array}$ & 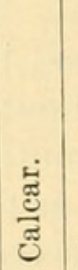 & 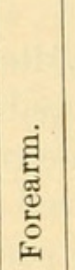 & 音 & 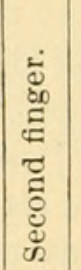 & 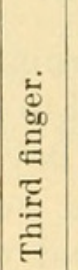 & 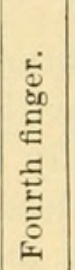 & 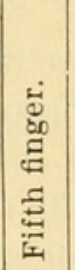 & 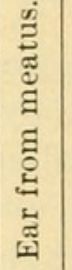 & 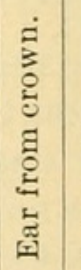 & 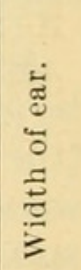 \\
\hline Great Nicobar. & 1111736 & Male... & $\begin{array}{c}M m . \\
260\end{array}$ & $\begin{array}{c}\mathrm{Mm} . \\
1250\end{array}$ & $\operatorname{Mm}$. & $\begin{array}{r}M m \\
54\end{array}$ & $\begin{array}{l}M m . \\
13\end{array}$ & $\begin{array}{c}\text { Mm. } \\
163\end{array}$ & $\begin{array}{r}M m . \\
70\end{array}$ & $\begin{array}{r}M m . \\
130\end{array}$ & $\begin{array}{c}M m \\
300\end{array}$ & $\begin{array}{c}M m . \\
245\end{array}$ & $\begin{array}{r}\mathrm{Mm} . \\
220\end{array}$ & $\begin{array}{r}M m_{28} \\
.\end{array}$ & $\underset{22}{M m}$ & $\begin{array}{c}\mathrm{Mm} . \\
19\end{array}$ \\
\hline Do & 1111737. & $\ldots$ do $\ldots .$. & 260 & 1185 & 75 & 51 & & 155 & 68 & 115 & 295 & 230 & 210 & 25 & 20 & 18 \\
\hline Do & 1111738 . & ... do .... & 247 & 1185 & 65 & 47 & 16 & 150 & 70 & 120 & 290 & 230 & 210 & 29 & 23 & 18 \\
\hline Do & 1111739 . & $\ldots$ do $\ldots .$. . & 280 & 1215 & 77 & & & 160 & 67 & 120 & 300 & 246 & 220 & 25 & 19 & 18 \\
\hline Do & ${ }^{1} 111740$. & $\ldots$. do .... & 260 & 1200 & & & 16. 6 & 156 & 72 & 120 & 310 & 240 & 220 & 30 & 25 & 19 \\
\hline Do & 2111748 & $\ldots$ do $\ldots$... & 300 & & 80 & & 18 & 170 & 70 & 130 & 330 & 245 & 220 & 30 & 23 & 22 \\
\hline Do . & 1111742 & Female. & 250 & 1180 & 76 & & 15 & 150 & 72 & 120 & 305 & 230 & 214 & 28 & 22 & 17 \\
\hline Tillanchong Island. & 1111731 & Male ... & 255 & 1180 & 76 & & 18 & 150 & 69 & 120 & 300 & 240 & 215 & 26 & 20 & 16 \\
\hline Do $\ldots \ldots \ldots$ & 1111732 . & $\ldots$ do $\ldots$... & 250 & 1170 & 73 & & 15 & 155 & 65 & 117 & 300 & 285 & 195 & 28 & 22 & 17 \\
\hline Do . & 2111746 . & ... do .... & 300 & & 78 & 50 & 15 & 157 & 60 & 120 & 310 & 235 & 210 & 27 & 22 & 18 \\
\hline Do . & 1111729 & Female. & & & 75 & & 17 & 150 & 70 & 115 & 295 & 228 & 207 & 27 & 22 & 16.6 \\
\hline & 1111733 . & ... do .... & 237 & 1170 & 72 & & 16 & 155 & 70 & 118 & 308 & 233 & 210 & 27 & 21 & 16.6 \\
\hline Do . & ${ }^{1} 111734$. & ... do ... & 250 & 1170 & 77 & & 18 & 157 & 70 & 120 & 300 & 237 & 215 & 28 & 20 & 16.6 \\
\hline Do. & 1111735 . & & 240 & 1150 & 74 & & 17 & 157 & 70 & 122 & 300 & 230 & 215 & 26 & 21 & 16 \\
\hline Do ... & ${ }^{2} 111747$ & ... do .... & 305 & ....... & 72 & & 20 & 150 & 68 & 120 & 290 & 230 & 200 & 24 & 20 & 18 \\
\hline
\end{tabular}


PTEROPUS FAUNULUS, new species.

Type.-Adult male (skin and skull) No. 111730, U.S.N.M. Collected on Car Nicobar, January 23, 1901, by Dr. W. L. Abbott. Original number 864 .

Characters.-A member of the subgenus Spectrum as defined by Matschie. Size very small (forearm $110 \mathrm{~mm}$.); ears triangular-pointed; color tawny, the face and back strongly tinged with hair brown; skull and teeth essentially as in Pteropus lepidus ${ }^{1}$ but much smaller.

Fur.-The fur of the back is silky in texture and closely appressed, the individual hairs $10-12 \mathrm{~mm}$. in length. On rump, thighs, and interfemoral region it becomes distinctly woolly in texture, though less so than on other parts of the body. It extends on leg to knee, below which there is a sparse sprinkling of hairs along inner surface of tibia. Fur of shoulders, head, neck, and underside of body loose and woolly in texture, therefore appearing much longer than that of back, though the length of the individual hairs is everywhere about the same. On under surface the fur extends about to knee and elbow. Beyond the latter point it is continued as a sparse sprinkling of fine hairs to middle of forearm.

Membranes.-The membranes show few peculiarities worthy of note. The uropatagium is reduced to a mere rim, except along legs, where it is about $12 \mathrm{~mm}$. in width. Between knee and body it is entirely concealed by the fur above, but only partially below. Propatagium naked above, sprinkled with fine hairs below. Wing membranes entirely naked above except for an inconspicuous sprinkling of fine hairs close to body and along forearm. Below they are scantily furred to line joining elbow and knee, also along forearm.

Ears.-The ears are of moderate size, proportionally about as in Pteropus lepidus, P. hypomelanus or P. nicobaricus and smaller than in $P$. meduis from Tenasserim and Lower Siam. In form they are quite distinct from those of any of the related species. Anterior border nearly straight from base to about middle, then after a faint convexity again nearly straight to tip. Extremity very narrowly rounded, less than $1 \mathrm{~mm}$. in width. Posterior border nearly straight from tip to a little above middle, than abruptly convex for a distance of a few millimeters; beyond this, nearly straight to slightly above small but distinct antitragal lobe. At tip the anterior and posterior borders form an angle of about $80^{\circ}$. The convexity of the posterior border is so abrupt as to be almost angular.

Color.-Back hair brown, considerably darker than Ridgway's Pl. III, fig. 12, everywhere intermixed with ochraceous buff. Anteriorly the brown is in excess of the buff, but posteriorly the buff becomes more conspicuous until on rump it practically excludes the darker

${ }^{1}$ For figure see Proc. Washington Acad. Sci., II, p. 238, August 20, 1900.

Proc. N. M. vol. xxiv-01-50 
color. The entire back is sprinkled with silvery whitish hairs which are most conspicuous anteriorly. Mantle, head and entire underparts ochraceous buff, brighter than that of back and strongly tinged with tawny on chest, sides of neck, and middle of breast and belly. Face, cheeks, and chin grizzled hair brown. Ear's and membranes blackish.

Skull and teeth. - The skull and teeth show a remarkable likeness to those of Pteropus lepidus, though immediately distinguishable by their much smaller size. The interorbital region is, however, actually broader than in the larger species, and the postorbital processes are more robust. Pterygoids distinctly convergent posteriorly, imparting to outline of interpterygoid space a distinctly lyrate form. The teeth both above and below agree almost exactly with those of Pteropus lepidus, except that the cusps are not as high and the crown is relatively wider between the cusps.

Measurements.-External measurements of type (from well-made skin): Head and body, $170 \mathrm{~mm}$; t tibia, 38; foot, 34 (30); calcar, 13.6; forearm, 110; thumb, 49 (38); second digit, 82; third digit, 220; fourth digit, 168; fifth digit, 153; ear from meatus, 22; ear from crown, 19; width of ear, 14 .

Cranial measurements of type: Greatest length, $54(64)^{1} \mathrm{~mm}$; basal length, 48.6 (60); basilar length, 46 (58); median palatal length, 28 (36); palatal breadth (between anterior molars), 9 (11.4); zygomatic breadth, $28(33.6)$; least interorbital breadth in front of postorbital processes, 7 (8); least interorbital breadth behind postorbital processes, 7.6 (7); breadth between tips of postorbital processes, 19 (21.6); greatest breadth of braincase above, roots of zygomata, 20.2 (22.8); greatest depth of braincase, 17.6 (17.8); occipital depth, 11.6 (11.8); depth of rostrum at middle of diastema, 7.8 (8); mandible, $40(50)$; maxillary toothrow (exclusive of incisors), 19 (25); mandibular toothrow (exclusive of incisors), 22 (27.6); crown of first upper molar, 3.4 by 2.6 ( 5.6 by 3 ); crown of first lower molar, 3.6 by 2 ( 4.4 by 2.4 ).

Specimens examined.-One, the type.

Remarks.-Pteropus fannulus is a very strongly marked species, easily recognized by its small size and pointed ears. The single specimen was shot in dark forest. It was apparently not very common. Pteropus nicabaricus, originally described from a Car Nicobar specimen was not found on the island by Dr. Abbott.

\section{PTEROPUS VAMPYRUS Linnæus.}

1869. [Pteropus edulis] var. Pachysoma giganteum Zelebor, Reise der österreichischen Fregatte Novara, Zool., I (Wirbelthiere), 1, Mamm., p. 10 (Car Nicobar).

1878. Pteropus edulis DoBson, Catal. Chiropt. Brit. Mus., p. 50.

There appears to be little doubt that a large Pteropus, not P. nicobaricus, occurs in the Nicobar Islands, and that the same, or a closely

\footnotetext{
${ }^{1}$ Measurements in parenthesis are those of the type of Pteropus lepidus.
} 
related form, inhabits the Andamans. Whether this animal is true Pteropus vampyrus or not I am unable to say, as Dr. Abbott obtained no specimens. The fact that Zelebor distinguished it under the name Pachysoma giganteum points strongly to the distinctness of the species. That Pachysoma giganteum is not Pteropus faunulus is shown by Zelebor's diagnosis, Gula malis maculaque inter frontem et oculos brunneo-nigris, genis, nucha et dorso superiore clare flavescente-castaneis, dorso reliquo, pectore et abdomine brunneo-nigris, pilis nonnullis albido vel pallide cinereo terminatis, and by the fact that it was referred as a variety to the very large Pteropus edulis (=vampyrus). Three flyingfoxes, therefore, have been taken on Car Nicobar, the large Pteropus vampyrus, the medium-sized P. nicobaricus, and the small P. faunulus.

\section{Genus CYNOPTERUS F. Cuvier.}

\section{CYNOPTERUS BRACHYSOMA Dobson.}

1871. Cynopterus brachysoma Dosson, Journ. Asiat. Soc. Bengal, XL, Pt. 2, p. 260. (South Andaman Island.)

The thick-bodied fruitbat is at present known from the type specimen only, an adult female obtained by Dr. Stoliczka on South Andaman Island ${ }^{1}$ in 1871 . This, however, is probably the species referred to by Blyth in the appendix to Mouat's Adventures and Researches among the Andaman Islanders ${ }^{2}$ under Cynopterus marginatus. He says:

The Cynopterus is the only species of bat as yet received from the Andamans; but Colonel Tytler writes word that "there is a great abundance of small bats on the island [South Andaman], and I am surprised that you have not received any."

\section{CYNOPTERUS BRACHYOTIS Müller.}

1873. Cynopterus marginatus var. andamanensis Dobson, Journ. Asiat. Soc. Bengal, XlII, Pt. 2, p. 201, September 8, 1873. (Andaman Islands.)

1876. Cynopterus brachyotus Dosson, Monagr. Asiat. Chiropt., p. 26.

It is very probable that the specific name andamanensis will eventually stand for this species, as the Cynopterus brachyotis of Müller was originally described from Borneo. Beyond the fact that Dobson's type specimen was procured among the Andaman Islands nothing is known of the status of this bat as a member of the fauna under consideration.

\footnotetext{
${ }^{1}$ See Blanford, Fauna of British India, I, p. 265, $1891 . \quad{ }^{2}$ P. 354, 1863.
} 


\section{CYNOPTERUS SCHERZERI (Zelebor).}

1861. Pachysoma scherzeri Fitzinger, Sitzungsber. Math.-Naturwissensch. Cl. Kais. Akad. Wissensch., Wien, XLII (1860), pp. 385, 390 (nomen nudum).

1869. [Cynopterus marginatus] var. Pachysoma scherzeri Zelebor, Reise der Fregatte Novara, Zool., I (Wirbelthiere), 1, Mamm., p. 13 (Car Nicobar).

1876. Cynopterus scherzeri DoBson, Monagr. Asiatic Chiroptera, p. 26 (Car Nicobar).

1888. Cynopterus scherzeri Blanford, Fauna British India, Mamm., p. 264, June, 1888. (Car Nicobar, Timor?).

Nothing is known of the habits of this animal except that it is commonly found hanging beneath the leaves of the cocoanut palm. It was first recorded by Fitzinger in his nominal list of the mammals collected by the members of the Novara Expedition. Dr. Abbott secured a single specimen, an adult female, on Car Nicobar, January 25, 1901. He saw several others.

The material at hand is not sufficient to determine the status of Cynopterus scherzeri. The animal is much like C. montanoi from Singapore, and $C \cdot \operatorname{sphin} x$ from the peninsula of India, but the ears are smaller, the color is darker (vandyke brown instead of cinnamon), and the pale phalanges are less contrasted with the blackish wing membranes. Skull apparently smaller and narrower than that of $C$. montanoi or C. sphinx.

Measurements of the Abbott specimen: Head and body, $100 \mathrm{~mm}$.; tail, 12.7; expanse of wings, 470 ; tibia, 25.6 ; foot, 16 (14); calcar, 6.4 ; forearm, 67; thumb, 28 (24); second digit, 47 (45); third digit, 122; fourth digit, 96 ; fifth digit, 90 ; ear from meatus, 15.6 ; ear from crown, 13 ; width of ear, 9. Skull: greatest length, 30.6; basal length, 28.4; basilar length, 26.8; median palatal length, 14 ; breadth of palate between anterior molars, 5. .; zygomatic breadth, 18.6; least interorbital breadth in front of postorbital processes, 7.4 ; breadth of braincase above roots of zygomata, 12.6; greatest depth of brain case, 11; occipital depth, 7.4; mandible, 24; maxillary tooth row (exclusive of incisors), 10.4; mandibular tooth row (exclusive of incisors), 11.4.

\section{Genus MACACUS Lacépède.}

\section{MACACUS LEONINUS (Blyth).}

1869. Macacus andamanensis BaRtLet, Land and Water, VIII, p. 57, July 24 (Port Blair).

1869. Macacus andamanensis Sclater, Proc. Zool. Soc. London, p. 467.

1888. Macacus leoninus Blanford, Fauna of British India, I, p. 18.

The Burmese pig-tailed monkey has been introduced among the Andaman Islands, according to Dobson. By Bartlet, however, it was regarded as indigenous. The former view is probably correct. Dr. Abbott did not meet with the animal. 
MACACUS UMBROSUS, new species.

1846. Macacus cynomolgus Blyth, Journ. Asiat. Soc. Bengal, XV, p. 367. (Nicobar Islands).

1869. [Inuus cynomolgus] var. a, Cercocebus carbonarius Zelebor, Reise der österreichischen Fregatte Novara, Zool., I (Wirbelthiere), 1, Mamm., p. 7. (Great Nicobar Island.)

Type--Adult male (skin and skull), No. 111795, U.S.N.M. Collected on Little Nicobar Island, Nicobars, February 25, 1901, by Dr. W. L. Abbott. Original number, 888.

Characters. - Similar to the Macacus 'cynomolgus' of the Malay Peninsula, but much darker and less yellowish in color. General hue of upper parts hair-brown, the hairs with faint pale annulations, but with no, trace of tawny.

Color.-Upper parts and outer surface of limbs nearly uniform hair brown, with a faint tinge of drab, the latter becoming more pronounced on sides. About $3 \mathrm{~mm}$. below the tip of each hair is a dull cream buff annulation $3 \mathrm{~mm}$. to $4 \mathrm{~mm}$. in width. These light rings, together with the glossy texture of the hairs, give the fur a changing aspect as viewed in different lights. They are slightly more numerous on crown, nape, buttocks, and posterior surface of thighs than elsewhere. On the crown and nape they are very sharply defined, but on buttocks and thighs they lose their distinctness, at the same time increasing in length. Tail dark drab above, almost black on proximal half, pale drab below. Under parts and inner surface of limbs scantily clothed with pale drab hairs of very silky texture, those bordering mouth distinctly darker than elsewhere.

Skull and teeth.-The skull and teeth so closely resemble those of Macacus "cynomolgus" that I can detect no tangible differences.

Measurements.-For external measurements see table, page 790 .

Cranial measurements of type: Greatest length (exclusive of incisors), $134 \mathrm{~mm}$; basal length, 102; basilar length, 96; least palatal length, 57 ; palatal breadth (between front molars), 25; zygomatic breadth, 90; mastoid breadth, 71; greatest breadth of braincase above roots of zygomata, 61 ; least breadth of braincase immediately behind orbits, 39 ; orbital breadth, 67 ; least distance from orbit to alveolus of inner incisor, 49; greatest depth of braincase (exclusive of sagittal crest), 50 ; mandible, 97 ; greatest depth of ramus, 19.6; maxillary tooth row (exclusive of incisors), 44.6; mandibular tooth row (exclusive of incisors), 50; crown of middle upper molar, 8.8 by 9 ; crown of middle lower molar, 8.2 by 7.4 .

Specimens examined.-Eight, from the following islands of the Nicobar group: Great Nicobar, 4; Little Nicobar, 2; Katchal, 2.

Remarks. - The series of eight specimens includes individuals of all ages from half-grown young to aged adults. Throughout the color is 
very constant, and no approach is shown to the tawny of Macacus "cynomolgus."

This monkey was supposed by Zelebor to be the same as Macacus carbonarius, an animal from Sumatra, described by F. Cuvier in the Histoire Naturelle des Mammifères. ${ }^{1}$ That such is not the case is clearly proved by Cuvier's description and figure, both of which refer to an individual of the tawny 'cynomolgus' type.

Macacus umbrosus has long been known as an inhabitant of the Nicobar Islands. It was recorded by Blyth as long ago as 1846. Blanford suggested that it might have been introduced, ${ }^{2}$ but the reasons for this supposition are not given.

Measurements of eight specimens of Macacus umbrosus.

\begin{tabular}{|c|c|c|c|c|c|}
\hline Number. & Sex. & $\begin{array}{c}\text { Total } \\
\text { length. }\end{array}$ & $\left|\begin{array}{c}\text { Head and } \\
\text { body. }\end{array}\right|$ & Tail. & Foot. \\
\hline 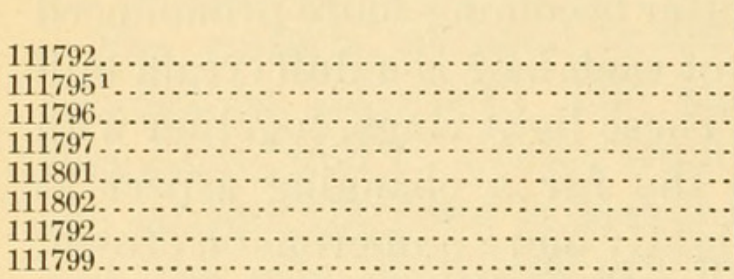 & $\begin{array}{l}\text { Male ad .... } \\
\text { Male ......... } \\
\text { Malo do } \ldots . . . . \\
\text { Male ad..... } \\
\text { Female.... } \\
\text { Female ad. }\end{array}$ & $\begin{array}{r}M m . \\
1,040 \\
1,085 \\
915 \\
1,025 \\
1,130 \\
790 \\
830 \\
960\end{array}$ & $\begin{array}{r}M m . \\
510 \\
505 \\
470 \\
475 \\
525 \\
360 \\
395 \\
460\end{array}$ & $\begin{array}{r}M m . \\
530 \\
580 \\
445 \\
550 \\
605 \\
430 \\
435 \\
500\end{array}$ & $\begin{array}{r}\text { Mm. } \\
135 \\
145 \\
135 \\
155 \\
150 \\
120 \\
120 \\
133\end{array}$ \\
\hline
\end{tabular}

1 Type. Weight, $8 \mathrm{~kg}$.

\section{SUMMARY.}

The mammal fauna of the Andaman and Nicobar islands is now known to consist of 35 positively identified species and 4 others whose status is still in doubt. ${ }^{3}$ Their distribution is shown in the accompanying tabular summary, in which the letter " $\mathrm{A}$ " indicates material obtained by Dr. Abbott, the letter " $\mathrm{R}$ " a previous record.

On comparing this fauna with that of other islands in the Malay region, ${ }^{4}$ two remarkable features are at once noticeable, the prevalence of bats and rats and the absence of practically all of the characteristic

${ }^{1}$ Vol. V, Pt. 52. October, 1825. Named in table, Vol. VII, p. 2, 1842.

${ }^{2}$ Fauna of British India, I, Mamm., p. 22, 1888.

${ }^{3}$ Two animals of known recent introduction are not included. These are the domestic goat on Barren Island, Andamans, and the buffalo on Kamorta Island, Nicobars. The goats were placed on Barren Island some years ago by the Port Blair authorities and at the time of Dr. Abbotts' visit had increased to several hundred. The buffalo on Kamorta are descendants of individuals left by the Danes when they abandoned their settlement. They are few in numbers, and Dr. Abbott and Mr. Kloss saw only their tracks. A pair of axis deer were placed in a favorable locality on one of the Nicobar Islands by Captain Lewis in 1846 (see Blyth, Journ. Asiat. Soc. Bengal, XV, p. 368), but it is unlikely that the species became established.

${ }^{4}$ See Miller, Mammals collected by Dr. W. L. Abbott on islands in the South China Sea (Proc. Washington Acad. Sci., II, pp. 203-246, August 20, 1900), and Mammals collected by Dr. W. L. Abbott on the Natuna Islands (Proc. Washington Acad. Sci., III, pp. 111-138, March 26, 1901). 
Malayan types, such as ungulates, squirrels, carnivores, and flyinglemurs, which abound on other islands at an equal distance from the mainland. This paucity of mammalian life can not be regarded as due to unfavorable surroundings, since all the natural conditions on both Andamans and Nicobars are perfectly suited to the support of a rich and varied fauna. In only one feature do the Andamans and Nicobars differ from such islands as Sumatra, Java, Borneo, the Natunas, Anambas, and Tambelans; they are surrounded by water of relatively great depth, while the others lie within the 50 fathom line. Doubtless this greater depth of water indicates separation from the mainland during a much longer period of time; and it appears safe to assume, therefore, that the Andamans and Nicobars, contrary to the case with the shallow-water islands, were isolated at a time when the mammals now characteristic of the Malay region did not exist there. As yet no species are known whose origin may be referred to the remote period of this land connection, but that such exist in the unexplored interior of the larger islands, particularly of the Andaman group, is not beyond the limit of possibility. Such mammals as are now known are evidently of very recent origin, as in scarcely an instance has their differentiation progressed further than in the case of members of the same genera found on islands lying in shallow water. The question at once arises, therefore, as to the means by which they have arrived where they now are. Flight from the mainland would readily account for the distribution of the bats; but the presence of the other mammals seems impossible to explain otherwise than through the agency of man. With the single exception of Tupaia nicobarica, ${ }^{1}$ all are types well known to be closely associated with man throughout the Malayan region. Moreover, the period of time necessary to the development of the peculiarities of the native Andamanese would undoubtedly be ample to allow the formation of any of the species known from either group of islands, since in a biologic sense it has been vastly longer to the smaller, more rapidly breeding animals than to man. The introduction, intentional or otherwise, of a pig, a monkey, a palmcivet, two or three species of rats, a shrew and perhaps also a treeshrew, at about the time when the various islands were peopled by their present human inhabitants, would amply account for the existence of the present mammal fauna with its striking peculiarities.

${ }^{1}$ It is worthy of note that this animal differs more conspicuously from its congeners than is the case with any of the other mammals. 
Synopsis of the mammal fauna of the Andaman and Nicobar islands.

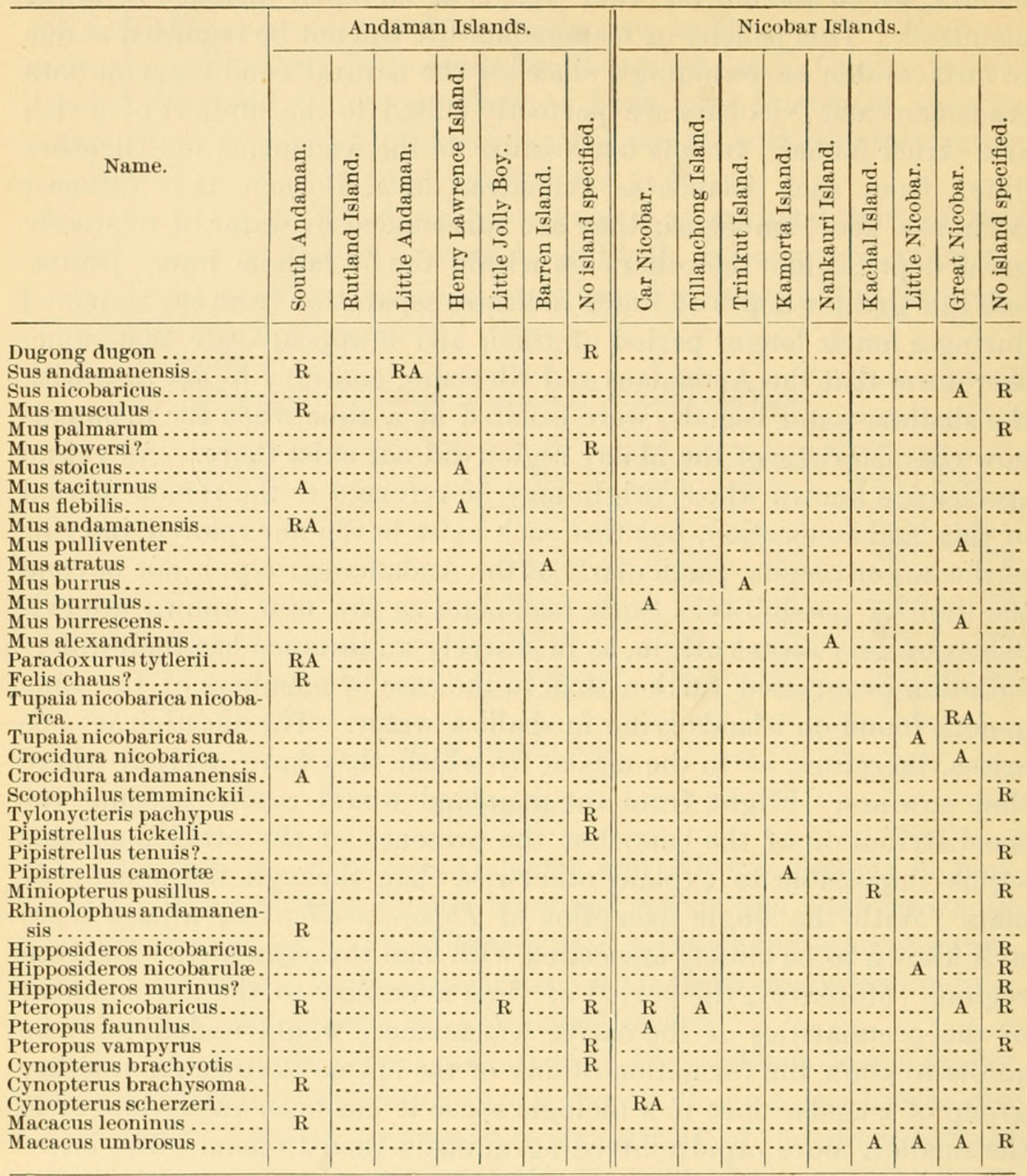

\section{BIBLIOGRAPHY.}

The following articles have been examined during the preparation of this paper. Though probably incomplete, the list is supposed to contain references to all the more important literature relative to the mammals of the Andaman and Nicobar islands.

Alexander, J. E. Notice regarding the Little Andaman Island, Bay of Bengal. Edinburgh New Philosophical Journal, II (October, 1826-April, 1827), pp. 43-48, pl. I, 1827.

An account of the landing of a party from the East India Company's transport Earl Kelly in search of water. Skulls of the Andaman pig mentioned (p. 46) and roughly figured (pl. I). 
Anderson, John. Catalogue of Mammalia in the Indian Museum. Calcutta, 1881.

The following mammals recorded from the Andamans and Nicobars:

Macacus carbonarius (Nicobars).

Pteropus nicobaricus (both groups).

Cynopterus marginatus (Andamans).

Cynopterus scherzeri (Nicobars).

Cynopterus brachysoma (Andamans).

Rhinolophus andamanensis (Andamans).

Phyllorhina (=Hipposideros) nicobarensis (Nicobars).

Phyllorhina (=Hipposideros) bicolor (Nicobars).

Vesperugo (=Tylonycteris) pachypus (Andamans).

Vesperugo (=Pipistrellus) tickelli (Andamans).

Vesperugo (=Pipistrellus) abramus (Nicobars).

Miniopterus pusillus (both groups).

Tupaia nicobarica (Nicobars).

Bartlett, A. D. Andaman monkey (Macacus andamanensis). Land and Water, VIII, July 24, 1869, p. 57.

The description is based on an adult female Macacus leoninus procured at Port Blair, South Andaman Island.

Blanford, W. T. A monograph of the genus Paradoxurus. Proc. Zool. Soc. London, 1885, pp. 780-808.

The Andaman Paradoxurus tytlerii regarded as identical with P. grayi (pp. 803, 805).

Blanford, W. T. Fauna of British India, I, Mammalia. 1888 (pp. 1-250) and 1891 (pp. 251-617).

The following species are stated to occur on the Andaman and Nicobar islands: Macacus leoninus (Andamans, probably introduced).

Macacus cynomolgus (Nicobars).

Felis chaus? (Andamans).

Paradoxurus grayi (Andamans).

Tupaia nicobarica (Nicobars).

Pteropus nicobaricus (both groups).

Pteropus edulis (both groups).

Cynopterus scherzeri (Nicobars).

Cynopterus brachyotis (Andamans).

Cynopterus brachysoma (Andamans).

Hipposideros nicobarensis (Nicobars).

Rhinolophus andamanensis (Andamans).

Miniopterus pusillus (both groups).

Pipistrellus tickelli (Andamans).

Mus rattus (Nicobars).

Mus bowersi (Andamans).

Mus musculus (Andamans).

Sus andamanensis (Andamans).

Blyth, Edward. Notes on the fauna of the Nicobar Islands. Journ. Asiat. Soc. Bengal, XV, 1846, pp. 367-379.

Contains brief notes on four mammals, Macacus cynomolgus(=umbrosus), Pteropus edulis (=nicobaricus), Cynopterus marginatus, and Hipposideros murinus, specimens of which were procured by Mr. Barbe and Captain Lewis, and also mention of the Nicobar pig, a second species of monkey, and a large squirrel, none of which were taken. It is also remarked (foot note, p. 368), that Captain Lewis turned out a pair of Cervus axis in a locality where he believed they would propagate.

Blyth, Edward. Report of Curator, Zoological Department, for May, 1858. Journ. Asiat. Soc. Bengal, XXVII, 1858, pp. 267-290.

Contains an account of the specimens procured by a native collector in the employ of the Asiatic Society, who accompanied Dr. G. von Liebig during a visit to the penal settlement at Port Blair. The pig, here for the first time described as Sus andamanensis, is the only mammal recorded. 
Blyth, Edward. Report of Curator, Zoological Department, for February to May meetings, 1859. Journ. Asiat. Soc. Bengal, XXVIII, 1859, pp. 271-298.

Bats occur on South Andaman Island, and also a rat, not of recent introduction, but none have been identified. A mouse, apparently the house mouse of India, has been taken from the stomach of a snake (Trigonocephalus) killed at Port Blair. Bones of Halicore indicus (=Dugong dugon) found in native hut.

Blyth, Edward. Report of Curator, Zoological Department. Journ. Asiat. Soc. Bengal, XXIX, 1860, pp. 87-115.

Two collections of "sundries" from Captain Hodge, Port Blair, have increased the known mammal fauna of the Andamans to five species: Paradoxurus musanga (=tytlerii), Mus andamanensis (here first described), Mus manei, and Halicore indicus (pp. 102-104).

Blyth, Edward. The Zoology of the Andaman Islands. Mouat's Adventures and Researches among the Andaman Islanders, 1863, appendix, pp. 345-367.

The first attempt to give a complete enumeration of the mammals of both Andamans and Nicobars. The following species mentioned:

Macacus cynomolgus (Nicobars).

Semnopithecus sp. (The large monkey seen, but not taken, by Captain Lewis.)

Pteropus nicobaricus (Nicobars; no flying fox on the Andamans).

Cynopterus marginatus (both groups).

Felis chaus? (Andamans).

Paradoxurus musanga (Andamans).

Mus andamanensis (Andamans).

Mus manei (Andamans).

Sus andamanensis (Andamans and apparently Nicobars also).

Dobson, G. E. Description of four new species of Malayan Bats. Journ. Asiat. Soc. Bengal, XL, Pt. 2, pp. 260-267. September 25, 1871.

Contains original descriptions of Cynopterus brachysoma from the Andamans and Phyllorhina (=Hipposideros) nicobarensis from the Nicobars.

Dobson, G. E. Brief descriptions of five new species of Rhinolophine Bats. Journ. Asiat. Soc. Bengal, XLI, Pt. 2, pp. 336-338. December 22, 1872.

Contains original description of Rhinolophus andamanensis.

DoBson, G. E. On the Pteropidæ of India and its islands, with descriptions of new or little-known species. Journ. Asiat. Soc. Bengal, XLII, Pt. 2, pp. 194-205. September 8, 1873.

Mentions the following species from the Andaman and Nicobar Islands:

Pteropus nicobaricus (both groups).

Cynopterus marginatus var. andamanensis (Andamans).

Cynopterus scherzeri (Nicobars).

Cynopterus brachysoma (Andamans).

Dobson, G. E. Monograph of the Asiatic Chiroptera. 1876. Mentions the following species from the Andaman and Nicobar Islands:

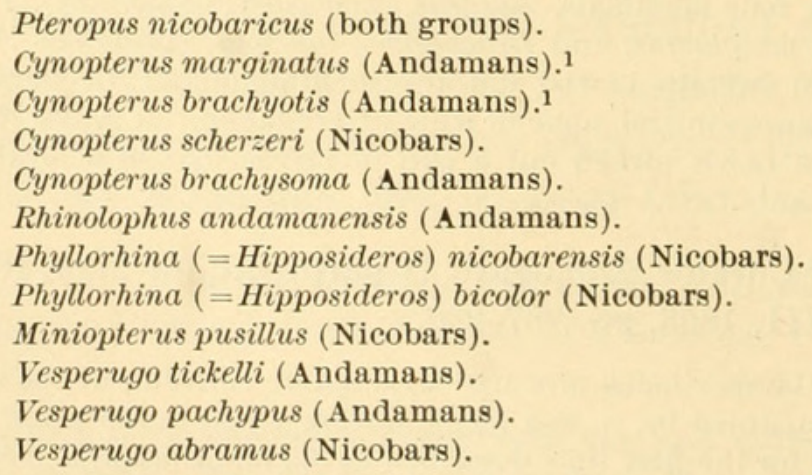

${ }^{1}$ Dobson regarded these as varieties of one species. It is not clear whether he intended to record both from the Andamans. 
Dobson, G. E. Catalogue of the Chiroptera in the collection of the British Museum. 1878.

In this work essentially the same bats are mentioned as occurring in the Andamans and Nicobars as are recorded in the Monograph of Asiatic Chiroptera. Pteropus edulis (=vampyrus) is added and several of the species mentioned in the Monograph are not positively stated to inhabit the islands.

Fitzinger, L. J. Die Ausbeute der österreichischen Naturforscher an Säugethieren und Reptilien während der Weltumsegelung Sr. Majestät Fregatte Novara. Sitzungsber. der Math.-Naturwissensch. Classe der kais. Acad. der Wissensch., Wien, XLII (1860), pp. 383-416. 1861.

A nominal list of the mammals and reptiles collected during the voyage of the Novara. The following mammals are from the Nicobars:

Cercocebus (= Macacus) carbonarius.

Pteropus nicobaricus.

Pachysoma (=Cynopterus) giganteum.

Pachysoma (=Cynopterus) scherzeri.

Vesperugo (=Pipistrellus) nicobaricus.

Cladobates (=Tupaia) nicobaricus.

Mus novaræ.

Mus palmarum.

Of these all but Pachysoma giganteum, Vesperugo nicobaricus, and Mus novaræ were afterwards described by Zelebor.

Gray, John Edward. Catalogue of Carnivorous, Pachydermatous, and Edentate Mammalia in the British Museum. 1869.

Sus andamanensis, pp. 336-337.

Gray, John Edward. Hand-list of the Edentate, Thick-skinned and Ruminant Mammals in the British Museum. 1873.

Sus andamanensis, p. 64 .

Hume, Allan O. Contributions to the Ornithology of India. The Islands of the Bay of Bengal. Stray Feathers, II, 1874, pp. 29-324.

Contains an account of a Pteropus, said to be $P$. nicobaricus, observed in large numbers on Little Jolly Boy, Andaman Islands.

Sclater, P. L. [Notice of a live monkey from Port Blair, Andaman Islands.] Proc. Zool. Soc. London, 1869, pp. 467-468.

The live specimen from Port Blair which had been described by Bartlet as Macacus andamanensis.

Tytrer, Colonel. Description of a new species of Paradoxurus from the Andaman Islands. Journ. Asiat. Soc. Bengal, XXXIII, 1864, p. 188.

Paradoxurus tytlerii.

Zelebor, Johann. Reise der österreichischen Fregatte Novara um die Erde in den Jahren 1857, 1858, 1859. Zool., I (Wirbelthiere), 1, Mammalia.

The following species are recorded from the Nicobar Islands.

Cercocebus (= Macacus) carbonarius.

Pachysoma (=Cynopterus) giganteum.

Pteropus edulis.

Pteropus nicobaricus.

Pachysoma (=Cynopterus) scherzeri.

Vesperugo (=Pipistrellus) tenuis.

Cladobates (=Tupia) nicobaricus.

Mus palmarum. 


\section{$2 \mathrm{BHL}$ Biodiversity Heritage Library}

Miller, Gerrit S. 1902. "The mammals of the Andaman and Nicobar Islands." Proceedings of the United States National Museum 24(1269), 751-795. https://doi.org/10.5479/si.00963801.24-1269.751.

View This Item Online: https://www.biodiversitylibrary.org/item/53718

DOI: https://doi.org/10.5479/si.00963801.24-1269.751

Permalink: https://www.biodiversitylibrary.org/partpdf/53111

\section{Holding Institution}

Smithsonian Libraries

\section{Sponsored by}

Smithsonian

\section{Copyright \& Reuse}

Copyright Status: Public domain. The BHL considers that this work is no longer under copyright protection.

This document was created from content at the Biodiversity Heritage Library, the world's largest open access digital library for biodiversity literature and archives. Visit BHL at https://www.biodiversitylibrary.org. 